\title{
THE VEGETATION AND HIGHER PLANT FLORA OF THE CRADLE MOUNTAIN-PENCIL PINE AREA, NOR'THERN TASMANIA
}

\author{
by J.B. Kirkpatrick and J. Balmer \\ (with four tables, six text-figures, three plates and an appendix)
}

\begin{abstract}
The Cradle Mountain-Pencil Pine area, northern Tasmania, has a highly varied vegetation and a rich and highly Tasmanian endemic flora. The distributions of the synusiae and floristic plant communities in the region are strongly influenced by geology, the altitudinal environmental gradient, drainage conditions and fire history.
\end{abstract}

Key Words: Tasmania, synusiae, plant communities.

In BANKS, M.R. et al. (Eds), 1991 (31:iii): ASPECTS OF TASMANIAN BOTANY - A TRIBUTE TO WINIFRED CURTIS. Roy. Soc. Tasm. Hobart: 119-148. https://doi.org/10.26749/rstpp.124.2.119

\section{INTRODUCTION}

The Cradle Mountain-Pencil Pine area has become the focus of development of the recreational/tourism resource of the Western Tasmanian World Heritage Area, with the construction of a major road link, a dramatic expansion in accommodation outside the park and the erection of an innovative visitor centre at its entrance. The flora and vegetation form one of the major attractions of the area. Although statewide studies have indicated the plant community composition of the area (Kirkpatrick 1983, 1986; Jarman et al. 1984, 1988a; Kirkpatrick et al. 1988; Whinam et al. 1989), their listings are based on limited sampling. There has been no general description of the vegetation and flora of the area since the pioneering study of Sutton (1928). In response to the need for a contemporary inventory of the biological resources of the area we have undertaken a quadrat-based study of community ecology, have mapped the distribution of synusiae and have listed all higher plant species that have been collected from, or observed in, the Cradle Mountain-Lake St Clair National Park.

\section{THE STUDY AREA}

The study area corresponds to that part of the Cradle Mountain-Lake St Clair National Park represented on the 1:25000 TASMAP topographic sheets "Cradle" and "Pencil Pine". It also includes the Pencil Pine Development Zone which lies directly to the north of the park (fig. 1).

The area has one of the coldest and wettest climates in Australia (table 1) in a landscape that has been heavily modified by glacial processes, and is lithologically varied (fig. 1). Peat formation has occurred at the higher altitudes on all substrates and at lower altitudes where drainage is poor or the soils are siliceous. Three major fires occurred in this area in the early years of this century or the late years of last century. Plates 1 and 2 provide striking evidence of the two more recent events, which burned the area between Barn Bluff and Cradle Mountain and the slopes below Hansons Peak. An older fire burned from the northwest over Hounslow Heath (fig. 2), and there are signs of many much older fires in the landscape. The lowland grasslands and sedgelands were burned at relatively frequent intervals from at least first European occupancy to the 1960's. Stem ages, from Jarman et al. (1988b) suggest that there were fires in 1916, 1935, 1941 and 1954. A fire, possibly caused by lightning strike, bumed part of the east of the study area in the last two to three decades (fig. 2).

\section{FLORISTICS OF THE RESERVE}

One of the first Australian species lists that indicated ecological occurrence was produced for the Cradle area by Sutton (1928). His plant census of the Cradle area recognised 287 plant taxa. Of these names, 101 are no longer used to represent Tasmanian taxa; a further 11 species are never likely to have occurred within the Cradle area (eg. Milligania longifolia, Epacris myrtifolia) and still others refer to taxa which have been merged with or split from others since the census (eg. Persoonia gunnii, Epilobium billardierianum). As a consequence, the value of Sutton's plant census has very much diminished. A current (although incomplete) 




FIG. I - Lithology map of Cradle Mt-Pencil Pine area.

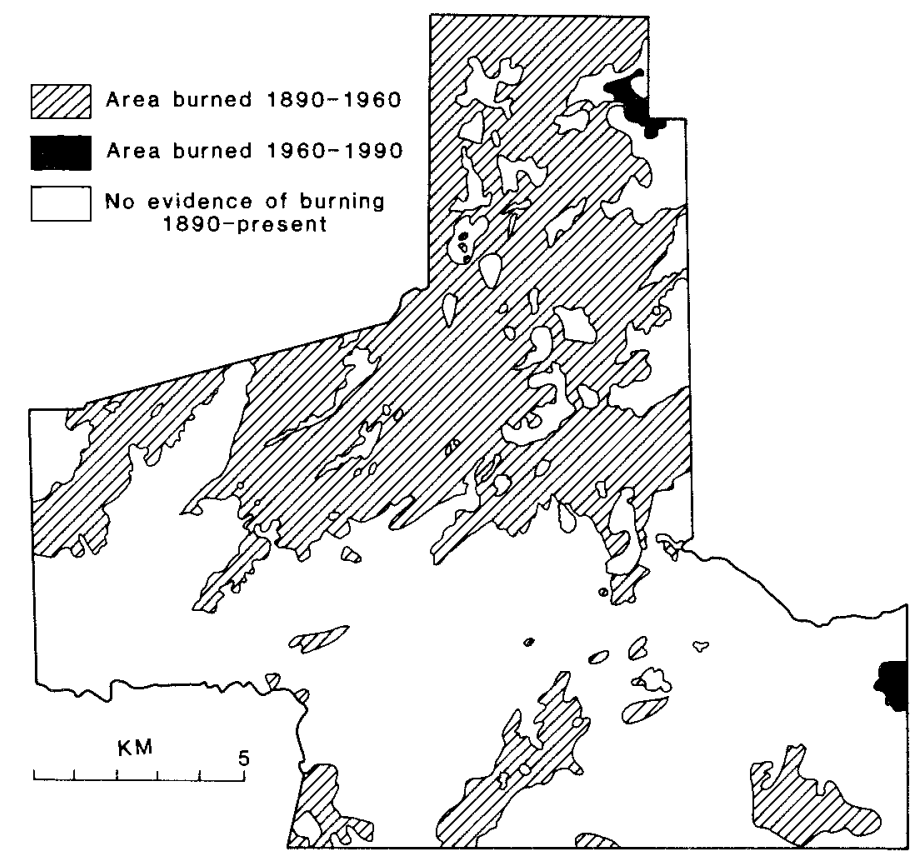

FIG. 2 - Fire history map of the Cradle Mi-Pencil Pine area. 
list of vascular plant taxa known to occur within the Cradle Mountain-Lake St Clair National Park is appended. Notes regarding the occurrence of species within the Cradle area are included.

Nearly one-third of Tasmania's vascular flora is located within the Cradle Mountain National Park. More than 450 native higher plant taxa from 79 families have been recorded. The families represented by the greatest number of native taxa are Asteraceae (58), Epacridaceae (39), Poaceae (36), Cyperaceae (31) and Myrtaceae (20). Only eight species of conifer and 34 ferns are recorded from the reserve. There are likely to be many more native monocotyledons than the 116 listed, since taxonomic keys are still not readily available. At least 164 of the native taxa within the reserve are endemic to Tasmania.

The lower plant flora is probably as diverse, if not more so, than the higher plant flora within the reserve. Unfortunately records and collections of the lower plant flora by specialist taxonomists are at preliminary stages. Nevertheless, substantial information on some of these groups now exists for some areas (Dr G. Kantvilas \& Dr S.J. Jarman, pers. comm., Parks, Wildlife and Heritage files).

Exotic species are not a major problem for park management, although at least 22 exotic weed species occur within the park. A number of others are historically planted garden species (e.g. a Califomian redwood planted near the Waldheim chalet - Ziegeler, pers. comm.). All seem to be restricted to the roadsides with the exception of Poa annua and Cerastium glomeratum which are also found close to huts and where sewage effluent has been dispersed.

The reserve is probably most important for its alpine flora, containing nearly 38700 ha of the state's alpine and subalpine vegetation. It also contains a range of other vegetation types (Kirkpatrick \& Dickinson 1984) including buttongrass moorlands ( $17600 \mathrm{ha}$ ), wet scrub ( $3800 \mathrm{ha}$ ) eucalypt forests ( 26400 ha including 8000 ha of old growth tall forest - Davies 1988) and cool temperate rainforests (39 400 ha). Specht et al. (1974) have listed the alliances occurring within the reserve and more recent systematic community studies have further sampled and described these communities (Jarman et al. 1984, 1988a, Kirkpatrick et al. 1988, Whinam et al. 1989)

The alpine areas contain an interesting mixture of eastern and western elements of the Tasmanian alpine flora (Kirkpatrick 1982, 1989). The central alpine province occupies a majority of the alpine area of the park. The other vegetation types are similarly dominated by what is an essentially central Tasmanian flora (in particular the Sphagnum peatlands, buttongrass moorlands and grassy communities). The reserve is located in the transition zone between the drier more fertile eastern part of the state and the wet infertile region to the west. In consequence, it is an area where a number of species reach the extreme in their distribution and many overlap. For example Eucalyptus amygdalina is largely replaced here by $E$. nitida and hybrid populations of these two species result in the vicinity of Lake St Clair. Similarly, in parts of the Cradle area $E$. nitida intergrades with $E$. coccifera over the altitudinal gradient (Shaw et al. 1984).

\section{THE PLANT COMMUNITIES}

\section{Methods}

All structural and floristic elements of the vegetation (synusiae) perceptible or interpretable from 1:25000 coloured aerial photographs were mapped after ground truthing and aerial reconnaissance. Fire boundaries were

\section{TABLE 1}

Climatic data for Cradle Valley

(Lat. $41^{\circ} 38^{\prime}$ Long. $145^{\circ} 57^{\prime}$. Elevation $914 \mathrm{~m}$ )

\begin{tabular}{lccccccccccccc}
\hline & $\mathbf{J}$ & $\mathbf{F}$ & $\mathbf{M}$ & $\mathbf{A}$ & $\mathbf{M}$ & $\mathbf{J}$ & $\mathbf{J}$ & $\mathbf{A}$ & $\mathbf{S}$ & $\mathbf{O}$ & $\mathbf{N}$ & $\mathbf{D}$ & $\mathbf{Y r}$ \\
\hline Mean daily max. temp. $\left({ }^{\circ} \mathrm{C}\right)$ & 17.2 & 17.6 & 14.7 & 11.2 & 7.5 & 5.1 & 4.6 & 5.2 & 6.6 & 9.8 & 12.0 & 14.0 & 10.5 \\
Mean daily min. temp. $\left({ }^{\circ} \mathrm{C}\right)$ & 6.3 & 7.8 & 5.9 & 4.3 & 1.5 & 0.1 & 0.1 & 0.0 & 0.3 & 1.6 & 3.0 & 4.0 & 2.9 \\
Mean rainfall (mm) & 147 & 135 & 154 & 228 & 280 & 275 & 320 & 307 & 275 & 251 & 219 & 183 & 2744 \\
Rain days & 16 & 14 & 18 & 20 & 21 & 21 & 24 & 23 & 22 & 21 & 19 & 18 & 237 \\
Mean days snow seen & 1 & 0 & 1 & 3 & 5 & 5 & 9 & 10 & 8 & 7 & 3 & 2 & \\
Mean days frost seen & 2 & 1 & 3 & 5 & 13 & 19 & 20 & 19 & 17 & 15 & 8 & 4 & \\
\hline
\end{tabular}

From Gutteridge et al. 1984: 36. 


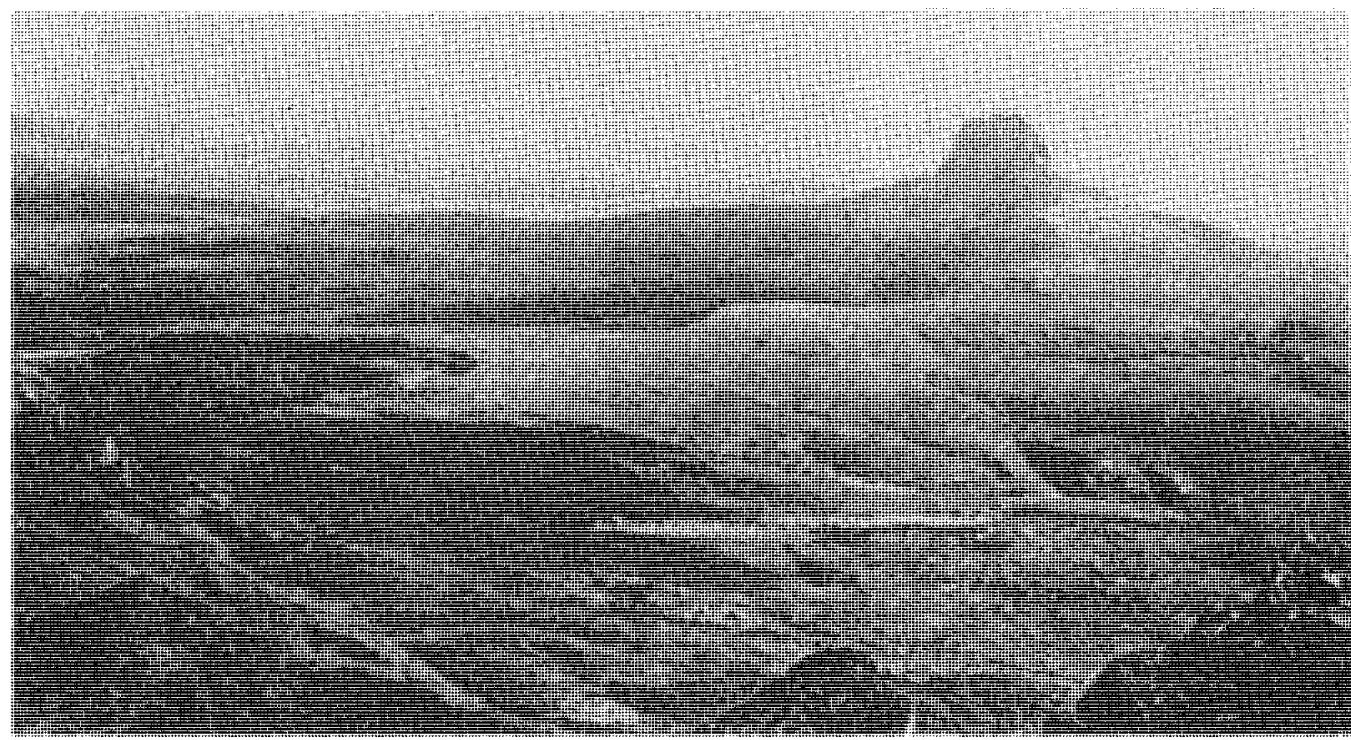

PLATE 1

Photograph taken in the 1920's of Barn Bluff, showing fire-killed vegetation.



PLATE 2

Photograph taken from Cradle Valley in the 1920's, showing fire-killed vegetation on the south side of Lake Dove. 
identified from these photographs, historical photographs and ground observations.

During March 1989, floristic presence and environmental data were collected from c. $4010 \times 10 \mathrm{~m}$ quadrats located subjectively without preconceived bias (Mueller-Dombois \& Ellenberg 1974) throughout the major environments of the study area. These data were supplemented by quadrats from the studies of Kirkpatrick (1986), Kirkpatrick \& Duncan (1987) and Cullen \& Kirkpatrick (1988) and by data from the files of the Department of Parks, Wildlife and Heritage. In all 141 quadrats were included in the analysis. Data on geology (five classes: 1 = basalt, 2 = dolerite and alluvium, 3 = fine grained sedimentary rocks, $4=$ glacial deposits, $5=$ coarse grained sedimentary rocks), slope (three classes: 1 = flat, $2=$ gentle slopes, $3=$ moderate and steep slopes), aspect (five classes: $1=$ northwest, $2=$ west and north, $3=$ southwest and northeast, $4=$ east and south, $5=$ southeast), altitude and species dominance were available for most quadrats. A fire susceptibility index was derived for the classificatory groups by attributing double the sum of the total percentage frequency of those taxa in table 2 known to be killed by fire and to lack any short-term mechanism for regeneration, and adding it to the sum of the percentage frequency scores of those species known to regenerate poorly after fire (Kirkpatrick 1984a). Other species scored zero. This sum was then divided by the number of taxa in the group that had percentage frequency values greater than 50 to give the final index.

The polythetic divisive programme TWINSPAN (Hill 1979) was used to aid the definition of floristic communities. Detrended correspondence analysis (Hill \& Gauch 1980) was used to ordinate the percentage frequency data for the TWINSPAN groups. For every split in the classificatory dendrogram, tests were made for significant environmental differences between the relevant two groups. Chi-squared was used for class data and the Student's t-test was used for parametrically distributed continuous data. Mean index and other environmental values were regressed against the first two axes of the ordination, and the residuals from the significant regression lines were tested against the remaining variables.

Species nomenclature follows Buchanan et al. (1989). Structural terminology follows Kirkpatrick (1983) for alpine vegetation, Gibson \& Kirkpatrick (1985a) for bolster heath, Jarman et al. (1984, 1988a) for rainforest and buttongrass moorland respectively, Kirkpatrick et al. (1988) for grassy vegetation and Specht (1981) for other vegetation.

\section{RESULTS AND DISCUSSION}

The species, life-form composition and environmental attributes of the 13 floristic groups selected from the TWINSPAN analysis are shown in tables 2 and 3 respectively (see pp. 138-140). The floristic groups partly overlap mapped synusiae. Their attributes and ecology and those of the synusiae are discussed below under four broad headings.

\section{Alpine Vegetation}

On dolerite and the argillaceous sedimentary rocks there is a sharp treeline at approximately $1200 \mathrm{~m}$ wherever drainage is good. On the skeletal soils of the siliceous sedimentary rocks the change in stature from tree to shrub is gradational, as on the West Coast Range (Kirkpatrick 1977). Alpine vegetation extends downslope to approximately $1100 \mathrm{~m}$, where there is a sharp boundary with Melaleuca squamea heath or Gymnoschoenus sphaerocephalus sedgeland, this boundary being most frequently evident on the siliceous rocks. Similar sharp boundaries have been noted elsewhere in Tasmania (Kirkpatrick \& Brown 1987).

There are four strong floristic groups within the alpine quadrat data set. They can be broadly characterised as alpine herbfield (group 3), bolster heath (group 12), heath on quartzite (group 11) and heath on dolerite (group 10). All of these units vary structurally and transgress the notional climatic treeline.

The most localised group (group 3, table 2) is mapped as alpine herbfield (fig. 3) and is associated with deep mineral soils formed on the erosion products of siltstones, usually below persistent snow patches. As described for a similar snow patch on Mt Field West (Gibson \& Kirkpatrick 1985b), the silt forms convex mounds covered by a closely-cropped herb-rich lawn. Wallaby and wombat scats are present in abundance. The most frequent and abundant species in these lawns are Poa gunnii, Erythranthera australis, Hydrocotyle sibthorpioides and Gnaphalium collinum. Helichrysum backhousii is the most common shrub found in these lawns, which usually grade into fjaeldmark upslope and abut on to deciduous or coniferous heath downslope and across slope. The alpine herbfield and grassland of snow patches and associated deposits is maintained in a tight sward by wallaby and wombat grazing. Shrub and tree seedlings are present but do not escape into adulthood.

In the more poorly-drained parts of the alpine zone three types of bolster heath are found, over-ridden to varying degrees by the dwarf pines Diselma archeri and Microcachrys tetragona. These are largely mapped as part of the coniferous heath and alpine heath 
Ac coniferous heath,ondolerite(d), on quartzitic conglomerate(q)

Ag alpine grassland

As al pineheath on dolerite(d), on quartzitic conglomerate(q)

$\mathrm{Fj}$ fjaeldmark

Ro rock or blockstream

Sb string bog

Sf snow patch fjaeldmark

\section{ALPINE PLANT COMMUNITIES}

Scale 1 : 95000

Ec Ercalyptus coccifera woodland/open forest

Ed Eucalyptus delegatensis open forest / tall open forest

Eg Eucalyptus gunnii woodland/open forest

En Eucalyptus nitida open scrub/open forest

Es Eucalyptus subcrenulata open forest

$B$ heathy sedgeland

G Poxgrassland

$\mathrm{H}$ herbfield

L Leptospermum/Melaleuca scrub/forest

$\mathrm{S}$ Sphagnum bog

Tm Milliganiatall alpine herbfield

$\mathrm{Tg}$ Restio/Empodisma/Gleichenia/Astelia, tall alpine herbfield

D deciduous heath/scrub/forest

$\mathrm{K}$ Athrotaxis selaginoides forest

P Athrotaxis cupressoides woodland/ forest

Rf evergreen closed forest

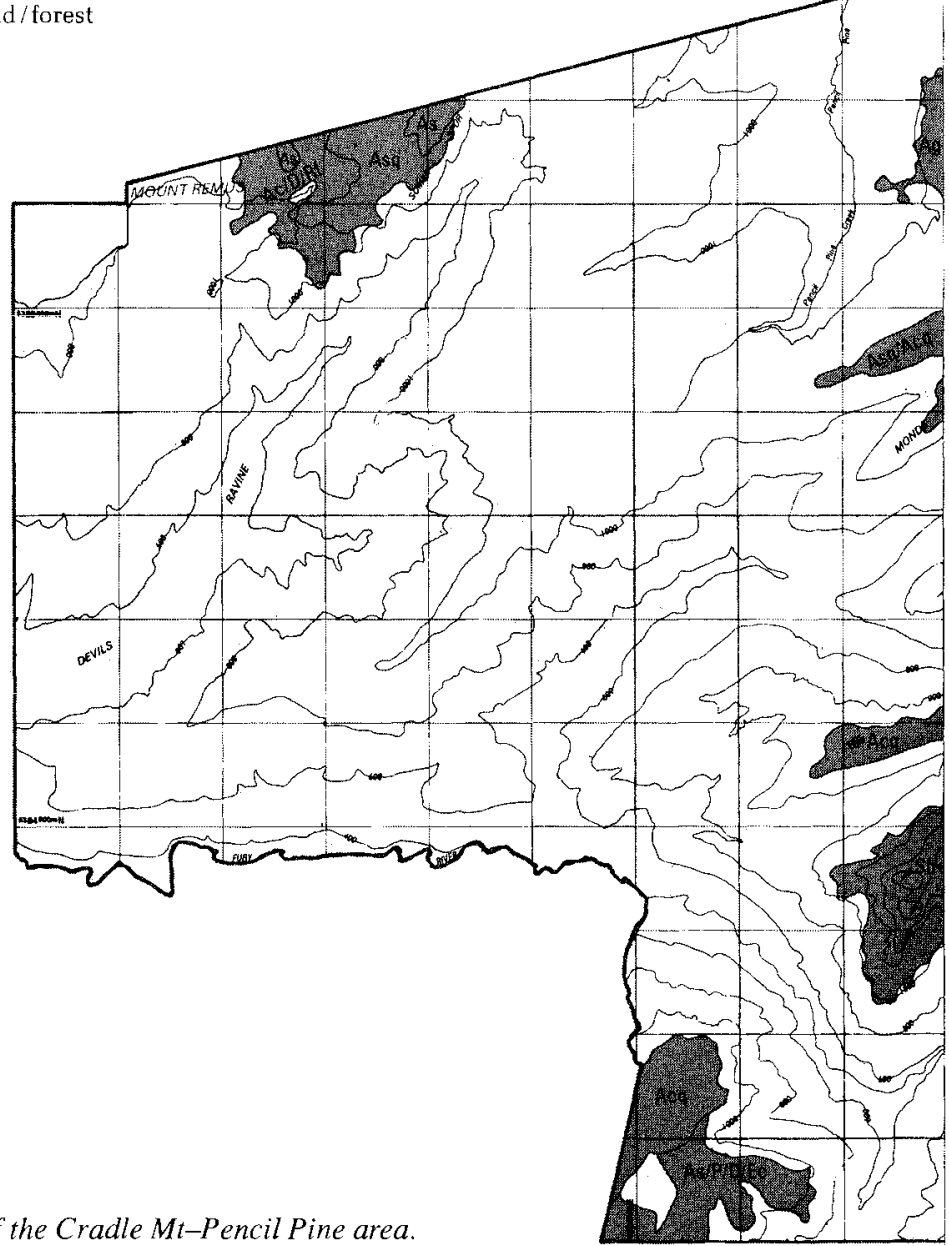




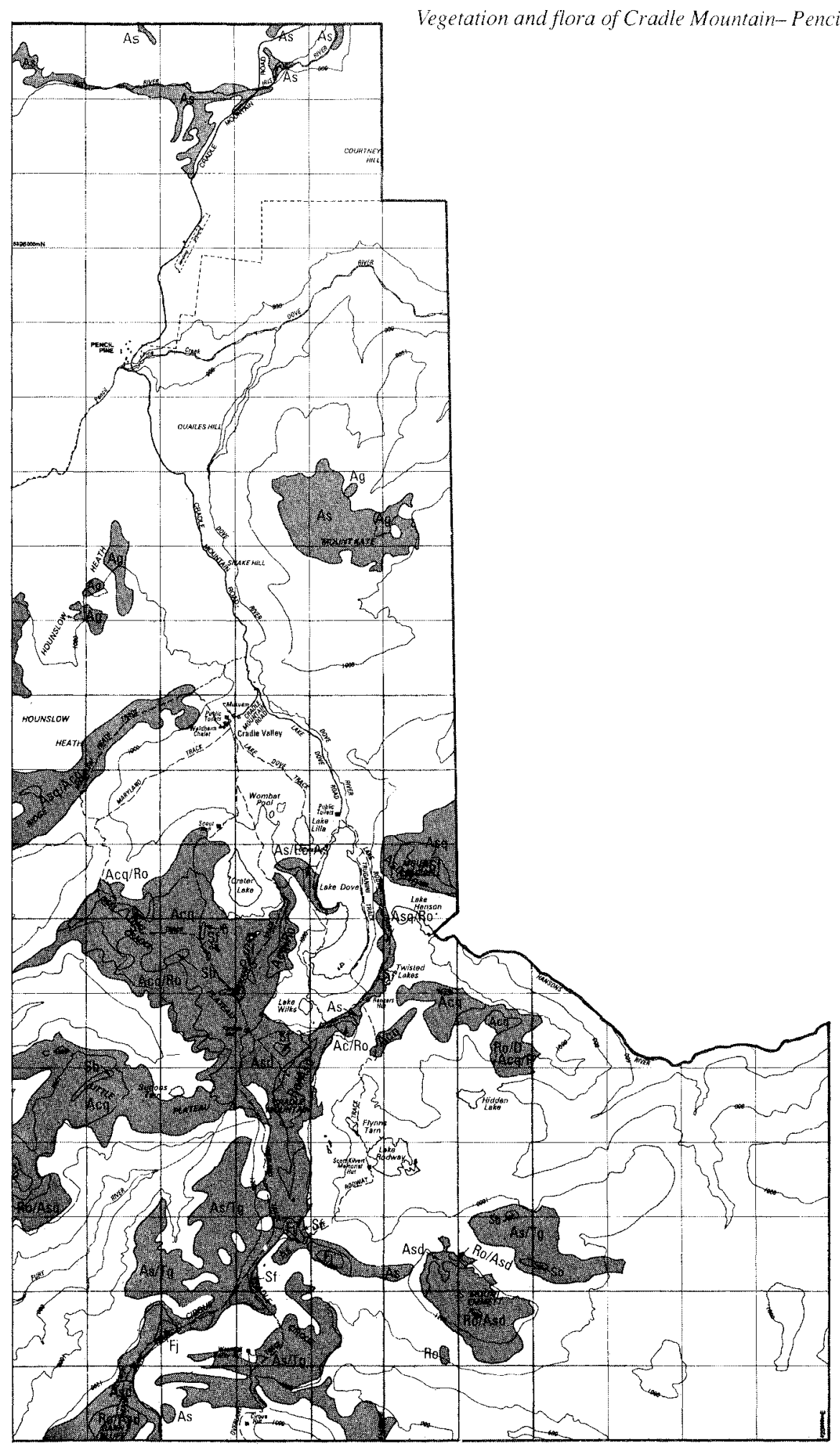


complexes, Near and on Bam Bluff Phyllachne colensoi high mountain cushion heath, paradoxically absent from Cradle Mountain, occurs on constantly wet slopes. The flush area below the one large snow patch on the dolerite peak of Cradle Mountain supports a mosaic cushion heath consisting of a mixture of Abrotanella forsteroides, Dracophyllum minimum, Donatia novaezelandiae and Pterygopappus lawrencei. On the siliceous plateaus the former species is absent from the mosaics and Donatia novae-zelandiae cushion heath is common. This latter type predominates on the poorlydrained pats of the more argillaceous sedimentary rocks. The floristic group that subsumes the bolster heath communities (12) has Epacris serpyllifolia, Pentachondra pumila and Empodisma minus as its most constant species.

The snow patches on quartzitic conglomerate have been mapped (fig. 3). Their vegetation differs markedly from that of the snow patches on siltstone and dolerite in that the sparse vegetation cover is evenly spread rather than patchy, and consists of a subset of the species of the adjacent bolster heath rather than having distinctive markers like Erythranthera australis and Gaultheria depressa. Thus, the fjaeldmark vegetation of the snow patches on siliceous rocks falls into group 12 , while that of the argillaceous snow patches falls into group 3.

Floristic group 11 corresponds largely with coniferous heath and alpine heath on quartzitic conglomerate, but also includes the most wind-exposed stands of Nothofagus gunnii, where it forms a prostrate heath plant. Microcachrys tetragona is the most frequent dominant in this floristic community, the other highly frequent species being Cyathodes dealbata, Ehrharta tasmanica, Pentachondra pumila, Richea sprengelioides and Exocarpos humifusus.

The final alpine floristic group (10) is found on both dolerite and the more finely-grained sedimentary rocks. It is thus found in coniferous and alpine heath on these substrates. The major dominant of the coniferous heath is Podocarpus lawrencei, while Orites revoluta and Richea sprengelioides dominate much of the alpine heath. This floristic group also subsumes most of the mapping unit labelled fjaeldmark and Milligania densiflora tall alpine herbfield. The fjaeldmark is closely similar to that described for Dome Hill (Kirkpatrick \& Whinam 1988) and Pyramid Mountain (Kirkpatrick 1984b), with stone steps turning into stone stripes with increasing steepness of slope, and with the features being best developed in the direction facing the prevailing winds. The Milligania herbfield is found below the dolerite columns of the major peaks where colluvium is constantly flushed with moisture. The most constant species of the floristic group are Podocarpus lawrencei, Tasmannia lanceolata, Orites revoluta and Richea sprengelioides while the species most characteristic of the group are $P$. lawrence $i_{\text {, }}$ Cyathodes straminea and Pimelea sericea.

The fires that burned parts of the alpine environment at the turn of the century have left substantial areas of alpine heath, much of it dominated by Richea scoparia, in which gymnosperms are infrequent or absent, contrasting markedly with their ubiquity elsewhere in the alpine zone. However, in the area burned earlier on the Hounslow Heath gymnosperms, especially Microcachrys tetragona and Podocarpus lawrencel, are more common.

\section{Treeless Low Altitude Vegetation}

The mapping units included in this general category are heathy sedgeland, Poa grassland, herbfield, Gleichenia tall alpine herbfield and Sphagnum bog (fig. 4). The mapping units seem less well-matched with the floristic groups than the alpine units because of the higher degree of local floristic heterogeneity.

Heathy sedgeland is the most widespread of these units. It is found on peaty soils of low nutrient status up to approximately $1100 \mathrm{~m}$ a.s.l. Pure buttongrass, layered eastern moor, common highland sedgey and highland dry sedgey communities are common within the mapped area, the former two communities being concentrated at lower latitudes and on apparently less fertile soils than the latter two. Gymnoschoenus sedgelands are most highly concentrated in floristic communities 9 and 13, although they also occur in communities 5 and 8 . The most frequent species in community 9 are Hibbertia procumbens, Ehrharta tasmanica, Mitrasacme montana, Lepidosperma filiforme, Lepyrodia tasmanica and Empodisma minus. This community occurs on highly siliceous rocks or deposits at relatively low altitude. On the steeper slopes that it occupies, Gymnoschoenus sedgeland eventually becomes overtopped by Leptospermum nitidum or Melaleuca squamea in the prolonged absence of fire, becoming physiognomically a heath then a scrub (mapped as Leptospermum \pm Melaleuca scrub). The scrub community is poorly-represented in the quadrat data, the one quadrat falling in group 13 .

Gleichenia alpina tall alpine herbfield occurs in situations that are better drained and more fertile than those occupied by sedgeland, but less so than those occupied by tussock grassland. Gleichena constitutes almost all the cover in the ground stratum. A sparse emergent layer of Richea pandanifolia characterises some areas of this vegetation type, which is concentrated in floristic group 13.

Poa tussock grassland occupies the most fertile and well-drained of the lowland treeless land, usually on 
deep, finely-textured, mineral, rock-free soils. Four of the grassy communities recognised by Kirkpatrick et al. (1988) occur within the study area. Poa labillardieriTrachymene humilis tussock grassland is found on the more fertile soils of the northem part of the study area, particularly those formed on basalt. Poa labillardieriVeronica gracilis tussock grassland is the commonest grassland community within the park. Poa labillardieri-Oreobolus distichus tussock grassland occurs adjacent to badly drained ground, and PoaScirpus tussock grassland occurs on silty, high-altitude sites subject to lushing. This latter community falls largely within the floristic group 3 of the present study and has been discussed under alpine herbland. The first community corresponds largely with our floristic group 1, while the other two fall within floristic group 2. The most frequent taxa in this latter group are $P o a$ labillardieri, Agrostis spp., Microseris lanceolata, Hydrocotyle sibthorpioides, Danthonia spp., Luzula spp. and Oreomyrrhis ciliata. Floristic group 1 is extremely rich in frequent species. These include the shrubs Bellendena montana, Epacris gunnii and Olearia algida, the grasses Deyeuxia quadriseta, Dichelachne rara, Elymus scabrum and Poa, and the herbs Geranium sessiliflorum, Hypericum japonicum, Leptorhynchos squamatus, Velleia montana, Scleranthus biflorus, Helichrysum rutidolepis, Ranunculus spp., Gonocarpus serpyllifolius, Acaena novae-zelandiae, Rubus gunnianus and Hydrocotyle sibthorpioides.

In the parts of the study area where stock have grazed after fire there has been little or no regeneration of tree species, although the intertussock flora is in a richer state than in the few grasslands within the National Park. These grasslands were burned and grazed in the past, but have been free of fire and introduced stock grazing for several decades. The rich flowering evident in plate 3 can no longer be found.

In the north of the study area, complex patterns of fluvial deposition and erosion have created considerable variation in drainage, inundation and nutrient conditions. Consequently heath, herbland, Sphagnum bog, tussock grassland and sedgeland occur in close juxtaposition. The herbland occurs on highly fertile flushes below rainforest and is dominated by a mat of Gunnera cordifolia. The heath is extremely herb-rich and is dominated by various combinations of Richea acerosa, Epacris gunnii and Richea gunnii. This latter species extends as a dominant to Sphagnum bogs. Many of the large bogs in the study area also support stands of Athrotaxis cupressoides. Four of the Sphagnum bog communities of Whinam et al. (1989) are found in the study area. These are subalpine coniferous mire, buttongrass-Sphagnum bog, Richea-Sphagnum bog and rainforest-Sphagnum mire.

\section{Communities Dominated by Eucalypts}

Eucalyptus delegatensis, E. nitida, E. coccifera, E. gunnii and E. subcrenulata are each found emergent over a variety of understorey types within the study area (fig. 5, pp.130-131). Eucalyptus delegatensis can be found with the widest variety of understorey, which includes tussock grasses, Gleichenia, scleromorphic shrubs, broad-leaved shrubs and rainforest. E. delegatensis is confined to well-drained sites on relatively fertile soils. It attains $1000 \mathrm{~m}$ on north-facing slopes. As well-drained soils become poorer in nutrients, $E$. nitida displaces $E$. delegatensis. The understorey to E. nitida grades from scleromorphic shrubs to rainforest. On the well-drained sites receiving the least summer heat that are occupied by eucalypts, E. coccifer $a$ replaces the previous two species. Whereas neither $E$. delegatensis nor $E$. nitida are strongly associated with any of our floristic communities, $E$. coccifera is the major dominant of two. Community 4 occurs on more fertile sites than community 8 . This difference is reflected in the most frequent species, which for 4 are Poa gunnii, P. labillardieri, Cyathodes parvifolia, Eucalyptus coccifera, Lycopodium fastigiatum, Coprosma nitida, Tasmannia lanceolata, Oxalis magellanica and Geranium potentilloides, whereas for community 8 they are Epacris serpyllifolia, Boronia citriodora, E. coccifera, Empodisma minus and Bauera rubioides. Eucalyptus gunnii and E. subcrenulata occur on more poorly-drained ground than the three species discussed above, with E. gunnii occurring on more fertile sites than the latter species. Both species can be found emergent from rainforest, scleromorphic shrubs, Gleichenia herbfield or sedgeland. Only E. gunnii can be found with an understorey of tussock grassland or Sphagnum bog. Whereas E. subcrenulata occurs sporadically in several floristic communities, E. gunnii is concentrated in community 5 . The most frequent species in this community are E. gunnil, Empodisma minus, Lycopodium fastigiatum, Hydrocotyle sibthorpioides and Ehrharta tasmanica.

\section{Rainforest}

Four rainforest synusiae have been mapped. The most general category is simply denoted as rainforest. This almost totally consists of forest dominated by Nothofagus cunninghamii, although Phyllocladus aspleniifolius and other evergreen angiosperm trees are often subordinate in the canopy. The deciduous tree, Nothofagus gunnil, and the gymnosperms, Athrotaxis selaginoides and $A$. cupressoides are also distinguished on the map (fig. 6, pp.132-133). The following communities of Jarman et al. (1984) have been 
B hoathy sedgeland

G Poigrassland

H herbfield

L Leptospermum/Melaleucascrub/forest

S Sphagnumbog

Tm Milligania tall alpine herbfield

Tg Restio/Empodisma/Gleichenia/Astelia, tallalpine herbfield

D deciduous heath / scrub/forest

$\mathrm{K}$ Athrotaxis selaginoides forest

P Athrotaxis cuprossoides woodland/forest

Rf evergreen closed forest

Ac: coniferous heath, on dolerite(d), on quartzitic conglomerate(q)

Ag alpine grassland

As alpine heath on dolerite(d).on (quartzitic conglomeratef(q)

Fj fja eldmark

Ro rock or block stroam

Ec Eucalyptus coccifera woodland open forest

Ed Eucaiyptus delegatensis open forest/tall open forest

Eg Eucalyptus gunnii woodland/open forest

En Eucalyptus nitida open strub/open forest

Es Gacalyptus subcremulata open forest

\section{TREELESS SUBALPINE PLANT COMMUNITIES \\ Scale $1: 95000$}

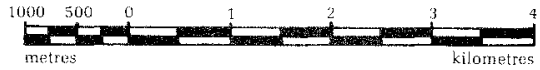

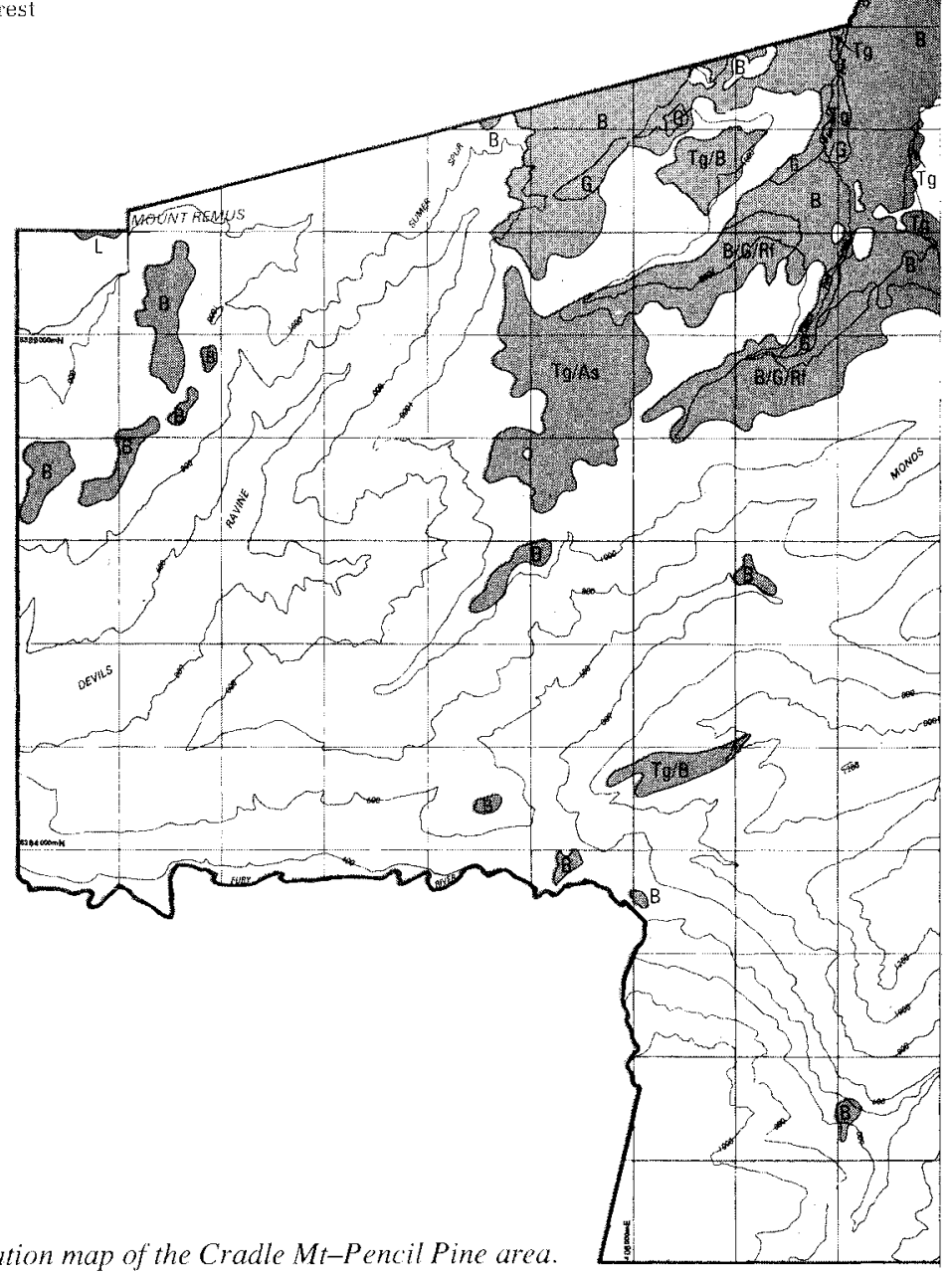

FIG. 4-Treeless subalpine vegetation map of the Cradle Mt-Pencil Pine area. 


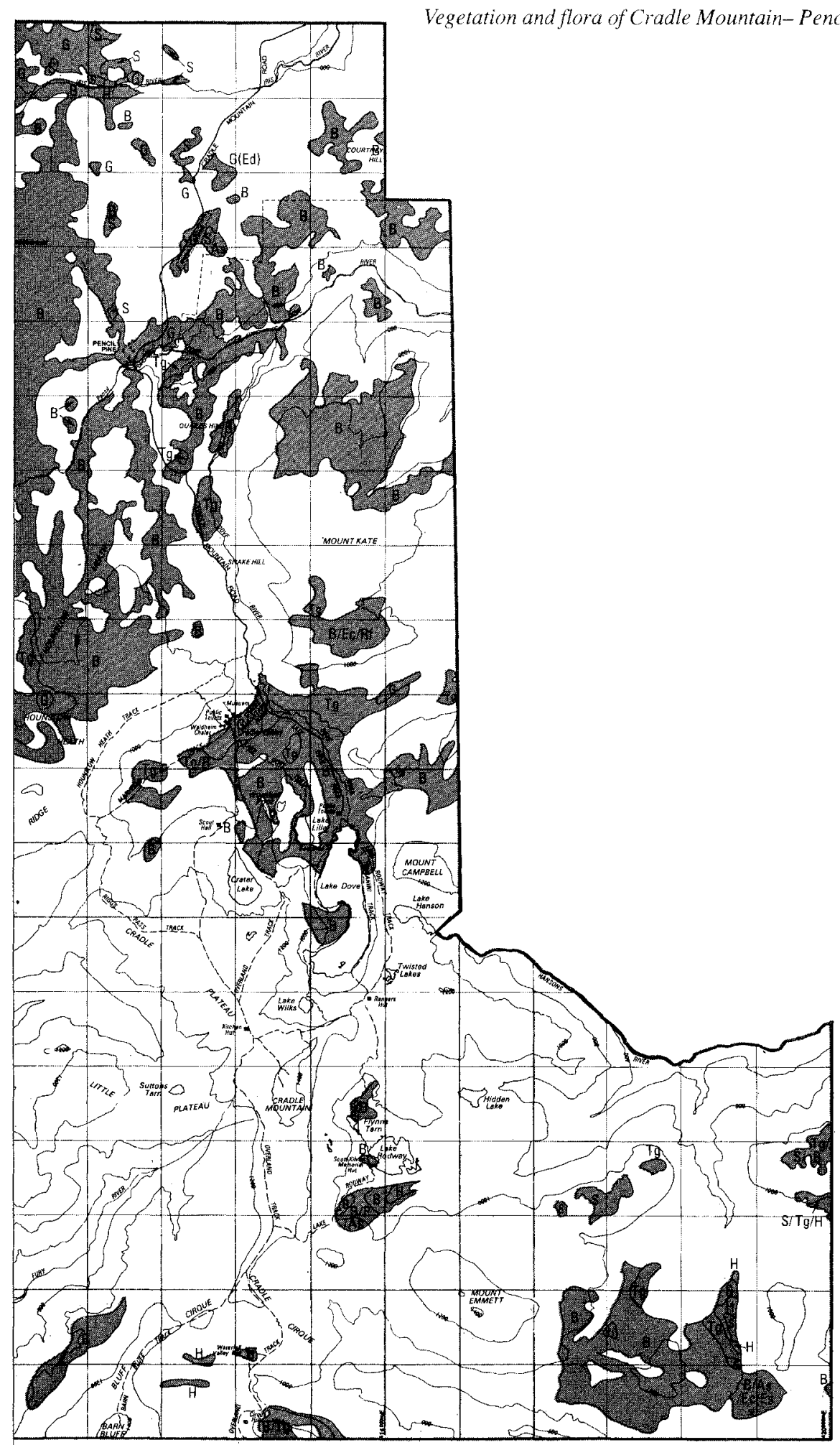


Ec Eucalyptus coccifera woodland/open forest

Ed Eucalyptus delegatensis open forest / tall open forest

Eg Eucalyptus gunnii woodland/open forest

En Eucalyptus nitida open scrub/open forest

Es Eucalyptus subcrenulata open forest

B heathy sedgeland

G Poagrassland

$\mathrm{H}$ herbfield

L Leptospermum/Melaleuca scrub/forest

S Sphagnum bog

Tm Milligania tall alpine herbfield

Tg Restio/Empodisma/Gleichenia/Astelia, tall alpine herbfield

D deciduous heath / scrub / forest

$\mathrm{K}$ Athrotaxis selaginoides forest

P Athrotaxis cupressoides woodland/forest

Rf evergreen closed forest

Ac coniferous heath,on dolerite(d), on quartzitic conglomerate(q)

Ag alpine grassland

As alpine heath on dolerite(d),on quartzitic conglomerate (q)

$\mathrm{Fj}$ fjaeldmark

Ro rock or block stream

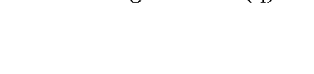

\section{EUCALYPT DOMINATED} COMMUNITIES

\section{Scale 1:95000}

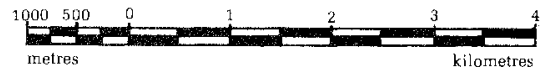

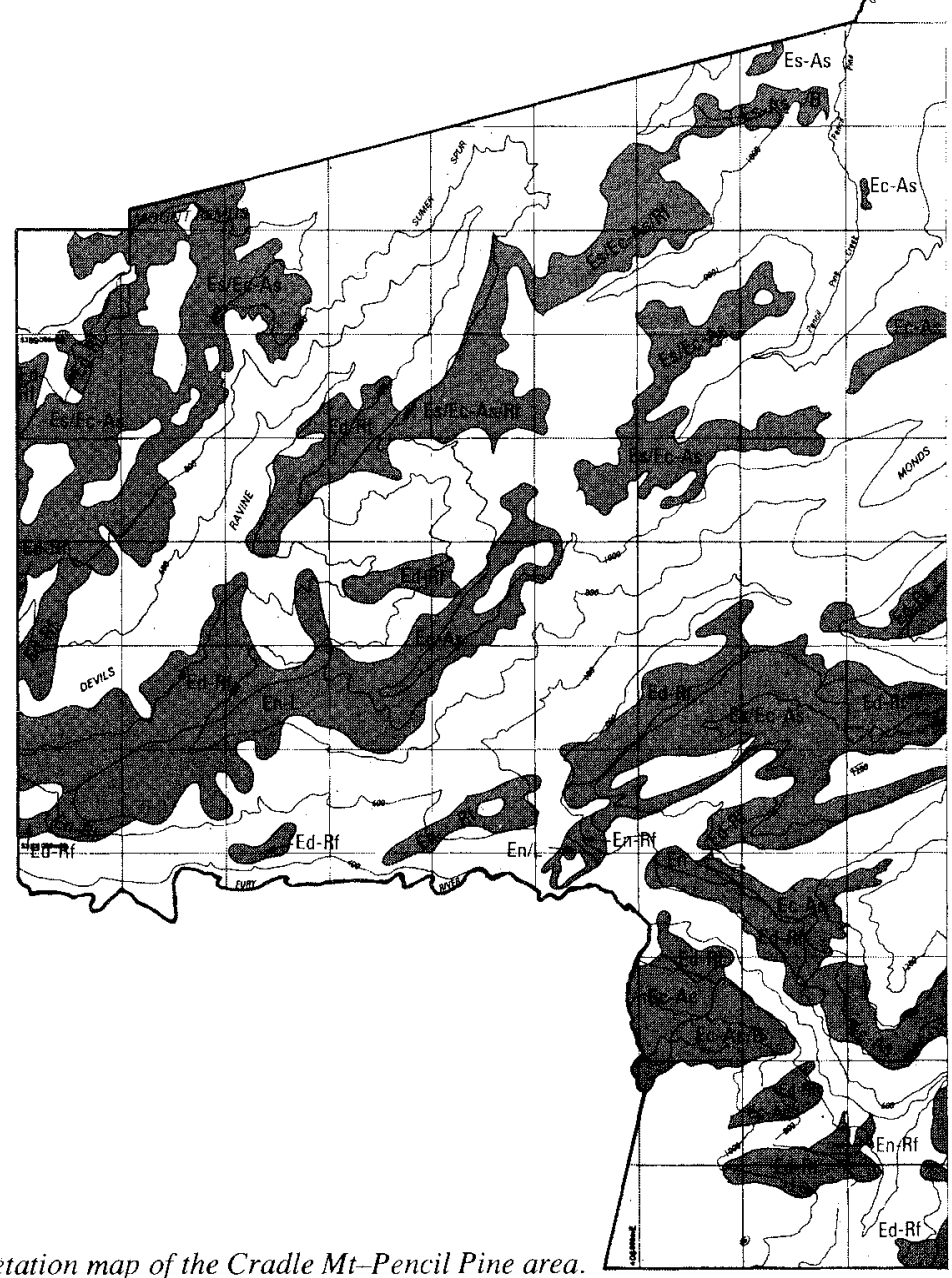


$\mathrm{D}$ decicuous heath / scrub/forest

$\mathrm{K}$ Athrotaxisselaginoides forest

P Athrotaxiscupressoides woodland/forest

Rf evergreen closed forest

Ac coniferous heath, on dolerite(d), on quart $\%$ itic conglomerate(q)

Ag alpir te grassland

As alpine heath on dolerite(d),on quartzitic conglomerate(g)

$\mathrm{Fj}$ fjaeldmark

Ro rock or blockstream

Ec Eucalyptus coccitera woodland/open forest

Ed Eucalyptus delegatensis open forest / tall open forest

Eg Eucalyptus gumnijwoodland/open forest

En Eucalyptus nitida open scrub open forest

Es Eucailiptus subronulata open forest

$B$ heathysedgeland

G Poagrassland

$\mathrm{H}$ herbfield

L Leptospermum/Melaleuca scrub/forest

S Sphagnum bog

Tm Milligania tall alpine herbfield

Tg Restio/Empodisma/Gleichenia/Astelia, tall alpine herbfield

\section{RAINFOREST PLANT COMMUNITIES \\ Scale 1: 95000}

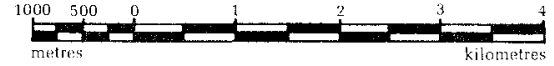

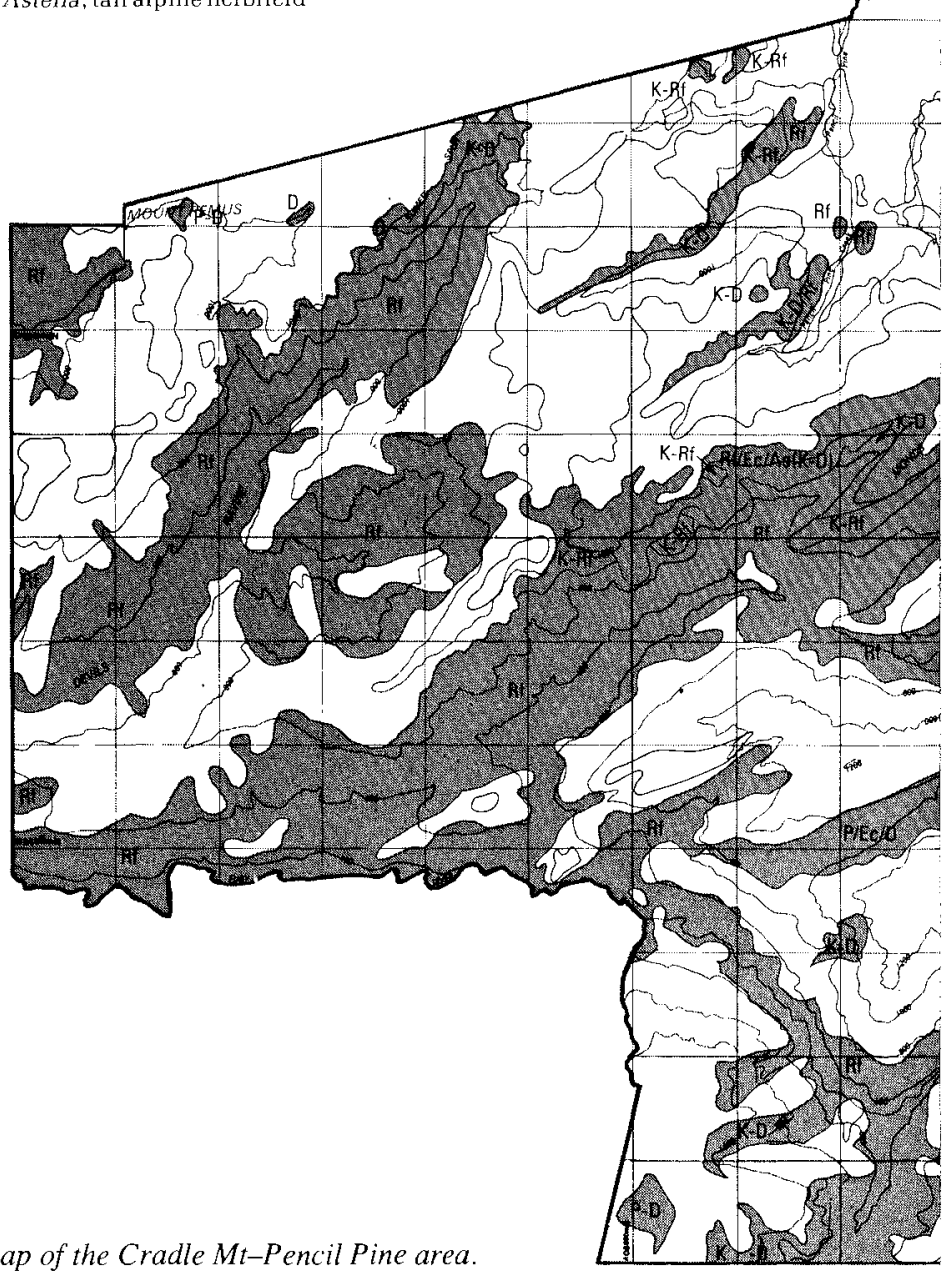




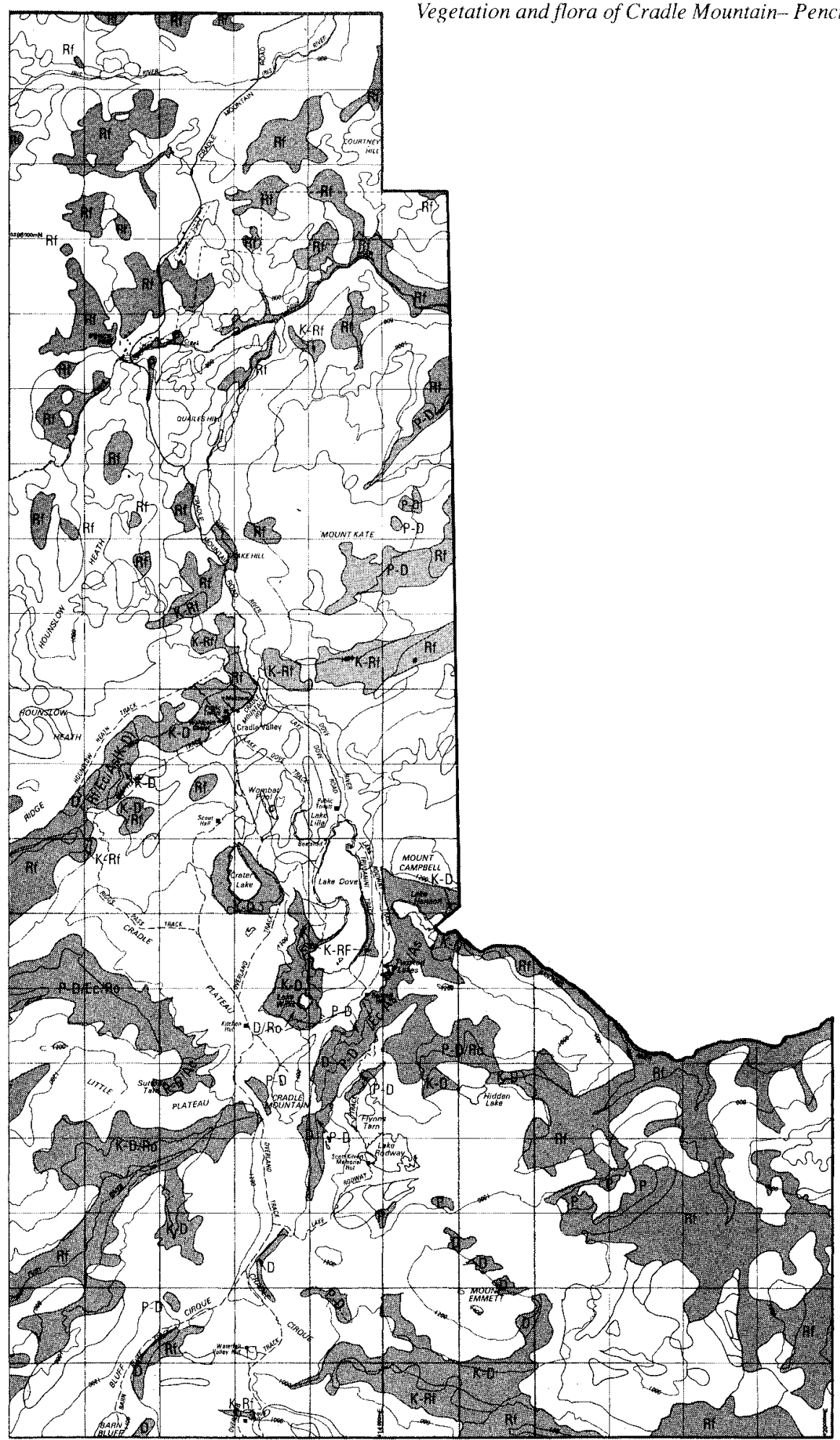




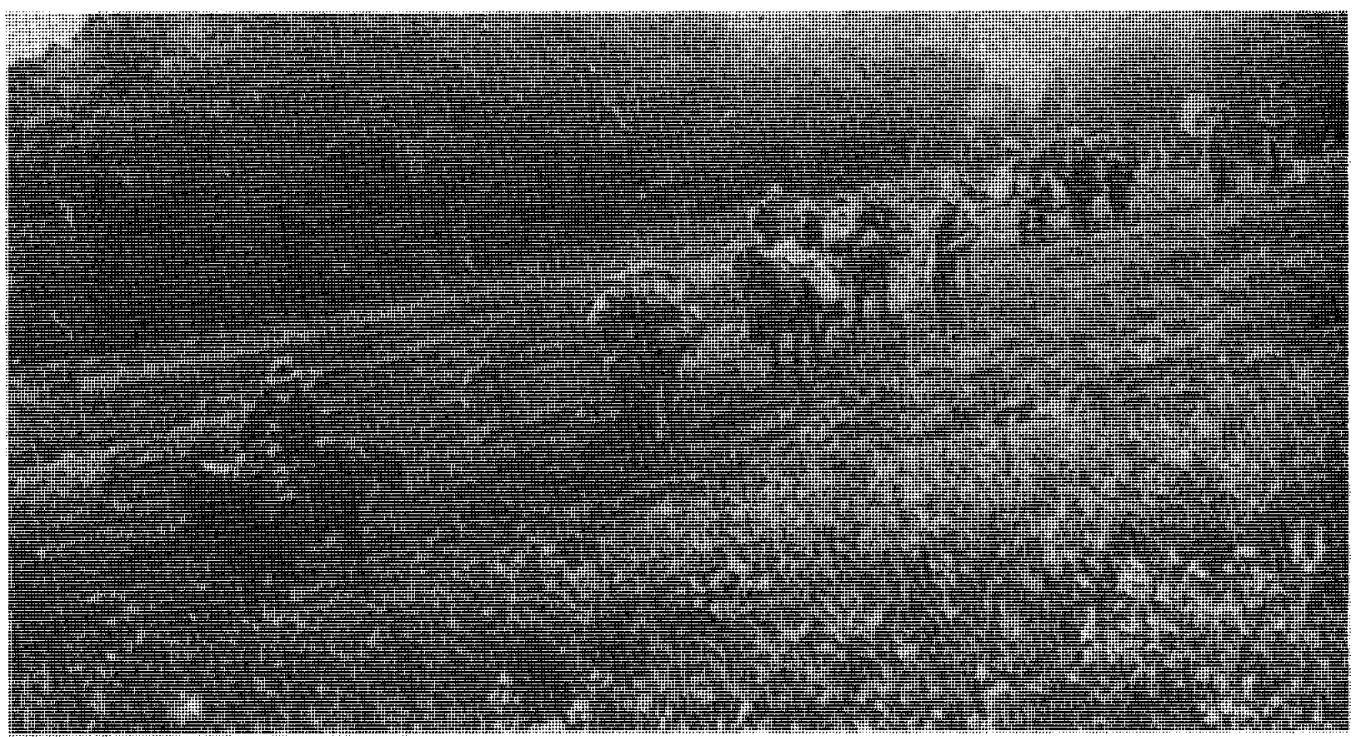

PLATE 3

Photograph taken in Cradle Valley in the 1920's, showing a prolific display of wildflowers in the grassland vegetation.

observed in the study area: callidendrous $1 \mathrm{~A}$ and $2 \mathrm{~A}$; thamnic $1 \mathrm{C}, 4 \mathrm{C}, 5 \mathrm{~B}$ and $5 \mathrm{C}$; implicate $2 \mathrm{~A}$; open montane 1,2 and 3 .

The floristic classification of the Cradle-Pencil Pine data set placed the rainforest sensu lato in three groups. Group 6 largely consisted of the quadrats in rainforest dominated by Athrotaxis selaginoides. The other most frequent species in these forests were Trochocarpa gunnii, Richea pandanifolia, Trochocarpa cunninghamii and Phyllocladus aspleniifolius. Group 7 has high concentrations of Nothofagus cunninghamii, Phyllocladus aspleniifolius and Athrotaxis cupressoides. The highest concentration of Nothofagus gunnii in a forest community is in group 8 where it is most often subordinate to Eucalyptus coccifera.

\section{Environmental Relationships}

The initial division in the classificatory analysis placed most of the sites on quartzitic conglomerate in the negative group and most of the sites on alluvium and basalt in the positive group (fig. 2). The quadrats in the group on infertile ground split into those of high-altitude and low-altitude sites with further significant environmental splits being on substrate, slope, altitude and fire history. The quadrats in the positive initial group split into further groups on slope and altitude.
The first axis of the ordination had an eigen value of 0.603 and was most closely correlated with the fire susceptibility index $(\mathrm{r}=0.713, \mathrm{df}=12, \mathrm{P}<0.01)$. The residuals from this regression were not significantly correlated with any of the measured environmental factors. The second axis of the ordination had an eigen value of 0.277 and was most closely correlated with altitude $(\mathrm{r}=0.866, \mathrm{df}=12, \mathrm{P}<0.001)$. The residuals from this regression line were significantly correlated with slope $(\mathrm{r}=0.610, \mathrm{df}=12, \mathrm{P}<0.05)$. In the cases of both axes, variability in the correlated attributes was close to parallel with the axes.

The results of the above analyses are consistent with a model of floristic variation in the vegetation of the area that is based on the causal roles of summer heat, waterlogging, soil nutrient status and fire regimes.

The upper altitudinal limit of trees within the Cradle area, and elsewhere in the state (Kirkpatrick 1982), correlates best with the mean temperature of the warmest month. Summer heat is greater on north than on southfacing slopes, making the upper limit of trees vary appropriately. The sharp boundary between treeless vegetation dominated by alpine species and treeless vegetation dominated by Gymnoschoenus sphaerocephalus occurs below the limit of trees but, like the treeline, varies in altitude with aspect (Kirkpatrick \& Brown 1987), suggesting that summer warmth may be 
critical in its determination. Eucalyptus delegatensis forest fits the same pattern. We suggest that the altitudinal floristic gradient indicated in the ordination analysis is largely a response to a decline in summer warmth with altitude, although it may also be influenced by variation in exposure to strong winds.

In the area above the treeline there is a strong relationship between slope and vegetation type, with cushion plants dominating the gentler situations and upright shrubs dominating on steeper slopes. This correlation seems best explained by moisture relationships as cushion plants can be dominant on quite steep slopes where seepage is constant.

Within the altitudinal zone potentially occupied by trees there are large treeless areas. The ratio of treeless to treed vegetation increases with decreasing slope at any one altitude, indicating that waterlogged conditions may be critical in inhibiting tree growth and establishment. Even if tree growth is not totally prevented by waterlogging, a slowing of growth rates would make individuals prone to being set back to ground level by fire, in the case of eucalypts, or lead to an open, and therefore more inflammable forest, in the case of rainforest trees. On poor soils below $1100 \mathrm{~m}$ heathy sedgeland occupies most of the treeless area. It forms an amorphous peat with low porosity which probably exacerbates drainage problems for trees.

Heaths rich in herbs and grasses, herblands and tussock grasslands occupy the more fertile treeless areas, some of which are clearly well-drained and most of which are sufficiently well-drained to support tree growth. On some sites, particularly the alluvial flats in the north of the study area, the absence of trees may relate to occasional severe frosts and the resistance of the surviving understorey sward to re-invasion (Slatyer 1989). Here, the topographic situation of the inverted treeline supports this hypothesis. The grasslands of Cradle Valley are likely to have an alternative origin. They occupy a well-drained and relatively productive slope and have a jagged and topographically varied boundary with adjacent rainforest. This boundary may have resulted from a single fire that killed rainforest on the lower slopes and then was reinforced by repeated fires within the regenerating vegetation. Alternatively, fires may have spread from frost-induced treeless vegetation at the base of the slope, merely extending, rather than creating, the grassland.

There is little doubt that fire has played a major role in the causation of vegetation patterning in the Cradle area. Fire sensitive species, such as Athrotaxis selaginoides, A. cupressoides, Nothofagus gunnii and Diselma archeri (Kirkpatrick \& Dickinson 1984, Brown 1988) often have jagged edges to their distributions that do not correspond with underlying environmental gradients, and size and age class analysis of stands reveals recolonisation from the margins of old burns. At the other extreme of fire frequency, comparison of grasslands and heathy sedgelands on similar sites with different times elapsed since fire suggests, that, over at least a part of their distributions, they require occasional fire for their maintenance. The pattern of juxtaposition of various lowland vegetation types fits closely with that which would be expected from the dynamic model of Jackson (1968). The ordination, like that of Kirkpatrick (1984a) in a similar environment, reflects the major phytosociological gradient from frequently burned to unburned sites.

The environmental gradient from argillaceous to siliceous rocks is associated with a floristic shift from relatively soft herbs and grasses to hard-leaved shrubs and graminoids and with some shift in forest, treeless lowland and alpine dominants on otherwise similar sites.

Fertility, summer heat and soil drainage interactively contribute to the potential growth rates for individual species. This integral response to the complex of environmental conditions is reflected most clearly in the structural/floristic gradient in the long, unburned rainforest.

On the best sites for tree growth, Nothofagus cunninghamii tends to form almost monospecific stands of callidendrous rainforest. As growth rates slow Athrotaxis species become dominant with progressively more complex and species rich understoreys. On the poorest sites for tree species growth, Nothofagus gunnii dominates a deciduous scrub. Within the Athrotaxis forest there is little doubt that $A$. cupressoides occupies more frost-prone sites than A. selaginoides (Cullen \& Kirkpatrick 1988).

\section{Conservation Management}

Table 4 (pp. 140-141) summarises the management and conservation attributes of the synusiae mapped in figures 3 to 6 . Our present knowledge of the ecology and conservation status of these synusiae suggests that a policy of total fire exclusion is appropriate for the preservation of the rainforest and alpine communities, and that management should be directed towards minimising the chances of fire entering these communities. The no campfire policy presently in force will aid this end, but the opening of the new link road to the northwest of Cradle Mountain will present a major ignition danger, both in itself as an attractor of arsonists and in the danger of escapes from the preventative burning it may encourage. We suggest that police or other Government patrols be placed on the susceptible sections of this road on dangerous days. In the long term, the survival of much of the area of 
eucalypt forest and lowland treeless communities may depend on a very occasional conflagration. These do not need to be encouraged. There is no convincing evidence of any totally fire-dependent species in the study area. Even the eucalypts will regenerate without fire in glacially-scraped country or on sharp ridges after tree fall.

The impact of trampling on the native vegetation has been much mitigated recently by track reconstruction, after a disastrous start (Calais \& Kirkpatrick 1986). The constuction of toilets has also mitigated the severe damage to alpine and subalpine root systems caused by the digging of holes for the deposition of faeces and paper. This latter activity is not appropriate in alpine vegetation where surface deposition is less environmentally damaging and no deposition is optimal.

The invasion of exotic species in the National Park is very much dependent on nutrient enrichment, which is only a problem around huts. In these locations Poa annua and Cerastium glomeratum are the major invaders. Exotics, if ever present, have not survived in the Cradle Valley grassland.

\section{ACKNOWLEDGEMENTS}

The authors thank Dr M.J. Brown for his constructive criticism of the manuscript.

\section{REFERENCES}

Buchanan, A.M., McGeary-Brown, A. \& Orchard, A.E., 1989: A CENSUS OF THE VASCULAR PLANTS OF TASMANIA. Tasm. Herb. Occ. Publ. 2.

BRiggs, J.D. \& LeIGH, J.H., 1988: RARE OR THREATENED AUSTRALIAN PLANTS. Aust. Nat. Parks Wildl. Serv. Spec. Publ. No. 14.

Brown, M.J., 1988: DISTRIBUTION AND CONSERVATION OF KING BILLY PINE. Tasmanian Forestry Commission, Hobart.

Brown, M.J., Kirkpatrick, J.B. \& Moscal, A., 1983: AN ATLAS OF TASMANIA'S ENDEMIC FLORA. Tasmanian Conservation Trust, Hobart.

Calais, S.S. \& KirkPatrick, J.B., 1986: The impact of trampling on the natural ecosystems of the Cradle Mt.-Lake St.Clair National Park. Aust. Geog. 17: 615.

Davies, J.B., 1988: Eucalypt species in Tasmania's tall forests. Report to Forestry Commission, Hobart.

Cullen, P.C. \& Kirkpatrick, J.B., 1988: The ecology of Athrotaxis D Don (Taxodiaceae) II. The distributions and ecological differentiation of $A$. cupressoides and A. selaginoides. Aust. J. Bot. 36: 561-573.

GiBSON, N. \& KIRKPATRICK, J.B., 1985a: A comparison of the cushion plant communities of New Zealand and Tasmania. N.Z. J. Bot. 23: 549-566.
Gibson, N. \& Kirkpatrick, J.B., 1985b: Vegetation associated with localised snow accumulation at Mount Field West, Tasmania. Aust. J. Ecol. 10: 91-99.

GuTTERIDGE, HASKINS, \& DAVEY, 1984: Environmental impact study: Link Road from Murchison Highway to Cradle Mountain Tourist Road. Unpubl. rep. Dep. of Main Roads, Hobart.

HILL, M.O., 1979: TWINSPAN-A FORTRAN PROGRAM FOR ARRANGING MULTIVARIATE DATA IN A TWO-WAY TABLE BY CLASSIFICATION OF INDIVIDUALS AND ATTRIBUTES. Cornell University, Ithaca.

Hrle, M.O. \& Gauch, H.G., 1980: Delrended correspondence analysis: an improved ordination technique. Vegetatio 42: 47-58.

JACKSON, W.D., 1968: Fire, air, water and earth - an elemental ecology of Tasmania. Proc. Ecol. Soc. Aust. 3: 9-16.

Jarman, S.J., Brown, M.J. \& Kantvilas, G., 1984: RAINFOREST IN TASMANIA. National Parks and Wildlife Service, Hobart.

Jarman, S.J., Kantvilas, G. \& Brown, M.J., 1988a: Buttongrass moorland in Tasmania. Tasmanian Forest Research Council Inc. Res. Rep. No. 2.

Jarman, S.J., Kantvilas, G. \& Brown, M.J., 1988b: A preliminary study of stem ages in buttongrass moorlands. Tasmanian Forest Research Council Inc. Res. Rep. No. 3.

KiRKPATRICK, J.B., 1977: Native vegetation of the West Coast region of Tasmania. $n$ Banks, M.R. \& Kirkpatrick, J.B. (Eds.): LANDSCAPE AND MAN, Royal Society of Tasmania, Hobart: 55-80.

KirkPatrick, J.B., 1982: Phytogeographical analysis of Tasmanian alpine floras. J. Biogeog 9: 255-271.

KiRKPATRICK, J.B., 1983: Treeless plant communities of the Tasmanian high country. Proc. Ecol. Soc. Aust. 12: $61-77$.

KirкPATRICK, J.B., 1984a: Altitudinal and successional variation in the vegetation of the West Coast Range, Tasmania. Aust. J. Ecol. 9: 81-91.

KirkPATRICK, J.B., 1984b: Tasmanian high mountain vegetation II. Rocky Hill and Pyramid Mountain. Pap. Proc. R. Soc. Tasm. 118: 5-20.

KiRKPatRICK, J.B., 1986: Conservation of plant species, alliances and associations of the treeless high country of Tasmania. Biol. Conserv 37: 43-57.

KirKPatrick, J.B., 1989: The comparitive ecology of mainland Australian and Tasmanian alpine vegetation. In Good, R. (Ed.): SCIENTIF/C SIGNIFICANCE OF THE AUSTRALIAN ALPS. Aust. Alps Nat. Parks Committee and Aust. Academy of Science, Canberra: 127-142.

KiRKPatrick, J.B. \& Brown, M.J., 1987: The nature of the transition from sedgeland to alpine vegetation in South West Tasmania: I. Altitudinal vegetation change on four mountains. J. Biogeog. 14: 539-550.

KirKPATRICK, J.B. \& DiCKINSON, K.J.M., 1984 VEGETATION MAP OF TASMANIA. 1:500,000 SCALE. Forestry Commission of Tasmania. 
Kirkpatrick, J.B. \& DunCAN, F., 1987: Distribution, community composition and conservation of Tasmanian high altitude grassy ecosystems, Aust. $J$. Ecol. 12: 73-86.

Kirkpatrick, J.B., Gilfedder, L. \& Fensham, R., 1988: CITY PARKS AND CEMETERIES: TASMANIA'S REMNANT GRASSLANDS AND GRASSY WOODLANDS. Tasmanian Conservation Trust, Hobart.

KiRKPATRICK, J.B. \& WhinaM, J.P., 1988: Tasmanian high mountain vegetation III. Lake Ewart, Dome Hill and Eldon Bluff. Pap. Proc. R. Soc. Tasm. 122: 145-164.

Mueller-Dombois, D. \& Ellenberg, H., 1974: AIMS AND METHODS OF VEGETATION ECOLOGY. Wiley, New York.

Shaw, M.J., POTTS, B.M., \& ReId, J.B., 1984: Variation in and between Eucalyptus nitida Hook, f, and Eucalyptus coccifera Hook.f. Aust. J. Bot. 32: 641-654.

SLATYER, R.O., 1989: Alpine and valley bottom treelines. In Good, R.(Ed.): THE SCIENTIFIC SIGNIFICANCE OF THE AUSTRALIAN ALPS. Aust. Alps Nat. Parks Committee and Aust. Acadademy of Science, Canberra: 169-184.
SPECHT, R.L., 1981: Conservation of vegetation types. In Groves, R.H. (Ed.): AUSTRALIAN VEGETATION. Cambridge University Press, Cambridge.

Specht, R.L., Roe, E.M. \& Boughton, V.H., 1974: Conservation of major plant communities in Australia and Papua New Guinea. Aust. J. Bot. Suppl. 7.

SutTon, C.S., 1928: A sketch of the vegetation of Cradle Mountain, Tasmania and a census of its plants. Pap. Proc. R. Soc. Tasm. 1928-1929: 132-159

Whinam, J., Eberhard, S., Kirkpatrick, J.B. \& Moscal, A., 1989: ECOLOGY AND CONSERVATION OF TASMANIAN SPHAGNUM PEATLANDS. Tasmanian Conservation Trust Inc., Hobart.

$$
\text { (accepted 10 August 1990) }
$$

J.B. Kirkpatrick

Department of Geography and Environmantal Studies, University of Tasmania, GPO Box 252C, Hobart, Tasmania, Australia 7001

J. Balmer

Department of Parks, Wildlife and Heritage, GPO Box 44A, Hobart, Tasmania, Australia 7001 
TABLE 2

The percentage frequency of species by TWINSPAN group*

\begin{tabular}{|c|c|c|c|c|c|c|c|c|c|c|c|c|c|c|}
\hline Group & $\mathrm{LF}^{\dagger}$ & 1 & 2 & 3 & 4 & 5 & 6 & 7 & 8 & 9 & 10 & 11 & 12 & 13 \\
\hline No. of quadrats & & 5 & 15 & 11 & 10 & 8 & 8 & 20 & 14 & 3 & 15 & 9 & 15 & \\
\hline Melaleuca squamea & $S$ & - & - & - & - & - & - & - & 14 & - & 7 & - & - & \\
\hline Sprengelia incarnata & $\mathrm{S}$ & - & - & - & - & - & - & - & 21 & 33 & - & - & 40 & \\
\hline Lycopodium laterale & Fcz & - & - & - & - & - & - & - & 14 & - & - & - & 7 & \\
\hline Erigeron stellatus & $\mathrm{Hrz}$ & 20 & - & 9 & 10 & 38 & - & - & 14 & 33 & - & 33 & 40 & \\
\hline Carpha alpina & Mtz & - & 27 & 18 & - & - & - & - & 14 & - & - & 22 & 80 & 3 \\
\hline Astelia alpina & Mtz & - & 7 & 36 & - & 13 & 13 & 25 & 14 & 33 & 27 & 33 & 67 & 0 \\
\hline Baeckea gunniana & $\mathrm{S}$ & - & - & - & - & 13 & - & 25 & 29 & 33 & - & 33 & 53 & 8 \\
\hline Drosera arcturi & Нra & - & - & - & - & - & - & - & - & - & 7 & - & 53 & 3 \\
\hline Oreobolus pumilio & $\mathrm{Mm}$ & - & - & 9 & - & - & - & 5 & 25 & - & - & 11 & 53 & 13 \\
\hline Gentianella diemensis & Hra & - & 20 & - & - & - & - & - & 7 & - & 20 & 47 & 60 & \\
\hline Mitrasacme montana & $\mathrm{Hm}$ & - & - & 9 & -- & - & - & - & 7 & 100 & - & 11 & 47 & \\
\hline Restio complanatus & $\mathrm{Mz}$ & - & - & - & - & - & - & - & 25 & 67 & - & - & 13 & \\
\hline Pultenaea species & $S$ & 20 & 7 & - & - & 25 & - & 15 & 43 & 67 & - & - & 7 & 50 \\
\hline Gymnoschoenus & & & & & & & & & & & & & & \\
\hline sphaerocephalus & $\mathrm{Mtz}$ & - & - & - & - & 25 & - & 5 & 21 & 100 & - & - & - & 50 \\
\hline Boronia citriodora & $\mathrm{S}$ & - & - & - & - & - & - & 15 & 86 & 33 & 40 & 33 & 53 & 63 \\
\hline pyllifolia & $S$ & - & - & 9 & - & - & - & 15 & 71 & - & 27 & 36 & 80 & 15 \\
\hline Microcachrys tetragona & Sgp & - & - & - & - & - & - & - & 7 & - & 13 & 67 & 53 & \\
\hline Nothofagus & $\mathrm{Td}$ & - & - & 36 & - & - & 25 & - & 57 & - & 7 & 56 & - & \\
\hline Exocarpos humifusus & $\mathrm{Sp}$ & - & - & - & - & - & - & - & 50 & - & 40 & 67 & 20 & \\
\hline Orites revoluta & $S^{2}$ & - & - & 36 & - & - & - & 45 & 43 & - & 87 & 44 & 20 & 13 \\
\hline Podocarpus lawrencii & Sgp & - & - & 18 & - & - & - & 15 & 14 & - & 80 & 33 & 7 & \\
\hline Cyathodes straminea & $\mathrm{s}$ & - & - & 9 & - & - & - & 15 & 7 & - & 60 & 33 & - & 13 \\
\hline Orites acicularis & $\mathrm{S}$ & - & 7 & 27 & - & - & - & 15 & 14 & - & 60 & 11 & 13 & 38 \\
\hline dia tasmanica & $\mathrm{Mz}$ & - & - & - & - & - & - & - & - & 67 & -- & - & - & 38 \\
\hline Stylidium g & $\mathrm{Hr}$ & - & - & - & - & 25 & - & 10 & 43 & 67 & 7 & - & 7 & 25 \\
\hline Hibbertia & $\mathrm{Sp}$ & - & - & - & - & 25 & - & 20 & 14 & 100 & - & - & - & \\
\hline Pentachondra pumila & $\mathrm{Sp}$ & - & - & - & - & 13 & - & 20 & 36 & 67 & 47 & 100 & 53 & 13 \\
\hline Richea sprengelioides & $S$ & - & - & - & - & - & - & 20 & 57 & - & 67 & 100 & 53 & \\
\hline Cyathodes petiolaris & $\mathrm{S}$ & - & - & - & - & - & - & - & 50 & - & 14 & 22 & - & 13 \\
\hline Monotocas & $\mathrm{s}$ & - & - & - & - & 38 & 13 & 25 & 57 & 33 & 7 & 11 & 7 & 13 \\
\hline Perso & $\mathrm{S}$ & - & - & - & - & - & 25 & 5 & 50 & - & - & - & - & \\
\hline Oxylob & $\mathrm{S}$ & - & - & - & - & 13 & - & 10 & 64 & - & - & 11 & - & \\
\hline Nothofagus cunninghamii & $\mathrm{T}$ & - & 13 & - & 30 & 25 & 88 & 75 & 57 & - & - & 22 & - & \\
\hline Phyllocladus & & & & & & & & & & & & & & \\
\hline aspleniifolius & $\mathrm{Tg}$ & - & - & - & - & - & 88 & 55 & 14 & - & - & - & - & \\
\hline Trochocarpa gunnii & $\mathrm{S}$ & - & - & - & - & - & 88 & 50 & 7 & - & - & - & - & \\
\hline Athrotaxis selaginoides & $\mathrm{Tg}$ & - & - & - & - & - & 88 & - & 36 & - & - & 11 & - & \\
\hline Trochocarpa & & & & & & & & & & & & & & \\
\hline cunninghamii & $\mathrm{S}$ & - & - & - & - & - & 88 & - & 36 & - & 7 & 44 & - & \\
\hline Bauerar & $\mathrm{Sp}$ & - & - & - & - & - & 50 & 20 & 93 & 67 & - & - & - & \\
\hline Diplarn & Mtz & 20 & 13 & - & - & 13 & - & 30 & 50 & 67 & 13 & 22 & 27 & \\
\hline Eucaly & $\mathrm{T}$ & - & 13 & - & 70 & - & - & 50 & 79 & - & 7 & - & 7 & \\
\hline Poa species & $\mathrm{Pt}$ & 40 & 67 & 82 & 80 & 63 & - & 45 & 29 & 67 & 80 & 33 & 53 & 05 \\
\hline Celmisia asteliifolia & $\mathrm{Hr}$ & - & 27 & 18 & - & 13 & - & 15 & 36 & - & 33 & 67 & 40 & \\
\hline Cyathodes dealbata & $\mathrm{Sp}$ & - & - & 18 & - & - & - & 10 & - & - & 7 & 67 & 47 & \\
\hline Empodisma minus & $\mathrm{Mz}$ & 20 & 60 & 27 & 40 & 88 & 13 & 60 & 64 & 100 & - & 56 & 87 & \\
\hline Ehrharta species & $\mathrm{P}$ & 40 & 33 & 9 & 70 & 88 & - & 65 & 36 & 100 & 27 & 67 & 67 & 100 \\
\hline Uncinia species & M & - & 40 & 73 & 40 & 13 & - & 60 & 21 & - & 27 & 56 & 20 & \\
\hline Richea scoparia & $S$ & - & 7 & 64 & - & - & 50 & 55 & 36 & - & 40 & 56 & 47 & \\
\hline Gono & $\mathrm{Sp}$ & 100 & 53 & 27 & 60 & 100 & 7 & 30 & 14 & 33 & 60 & - & 7 & \\
\hline Cyathodes parvifolia & $S$ & 20 & 13 & - & 100 & 50 & 38 & 75 & 57 & 33 & 7 & - & - & \\
\hline Lepidosperma filiforme & Mtz & - & 33 & - & - & 50 & - & 20 & 57 & 100 & - & - & - & \\
\hline
\end{tabular}


Group

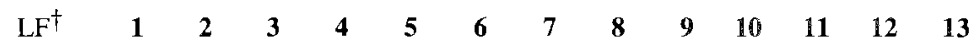

No. of quadrats

$\begin{array}{lrrrrrrrrrrrrr} & 5 & 15 & 11 & 10 & 8 & 8 & 20 & 14 & 3 & 15 & 9 & 15 & 8 \\ \mathrm{Fz} & 20 & 20 & - & 20 & 50 & - & 20 & - & 33 & - & 11 & 33 & 75 \\ \mathrm{~S} & 20 & 13 & 18 & 70 & 63 & 13 & 40 & 21 & - & 67 & 11 & - & - \\ \mathrm{S} & 40 & - & 45 & 80 & 63 & - & 55 & 43 & - & 73 & 22 & - & - \\ \mathrm{Mz} & 20 & 47 & - & 10 & 50 & - & 15 & - & 67 & - & - & - & 50 \\ \mathrm{~S} & 80 & 27 & 55 & 30 & 13 & - & 10 & 7 & - & 53 & 22 & 7 & 13 \\ \mathrm{Hrs} & 60 & 60 & - & 10 & 50 & - & 10 & - & 67 & - & - & - & - \\ \mathrm{Hcs} & 100 & 93 & 91 & 60 & 75 & - & 15 & - & 33 & - & - & - & 13 \\ \mathrm{~S} & 60 & 27 & 73 & - & 50 & - & 25 & - & 33 & 40 & 11 & - & - \\ \mathrm{Fcz} & 40 & 20 & 55 & 80 & 75 & - & 40 & 14 & 33 & 40 & 22 & 27 & - \\ \mathrm{Hrz} & - & 40 & 73 & 70 & 50 & - & 40 & - & - & - & - & 7 & - \\ \mathrm{Hrs} & 80 & 53 & 45 & 70 & 50 & - & - & - & - & - & - & - & - \\ \mathrm{S} & 80 & - & - & 10 & 63 & - & 15 & - & - & 7 & - & 13 & 13 \\ \mathrm{Hrc} & 100 & 53 & 36 & - & 63 & - & 45 & - & 33 & 27 & - & 20 & 25 \\ \mathrm{~T} & 40 & 7 & - & 60 & 75 & 20 & - & - & - & - & - & - & - \\ \mathrm{S} & 40 & 20 & - & - & 50 & 13 & 20 & - & 33 & - & - & - & - \\ \mathrm{Hr} & 20 & 27 & 45 & 20 & 63 & - & 35 & - & 3 & 20 & - & - & - \\ \mathrm{Sp} & - & - & - & - & 63 & - & 15 & - & - & - & - & - & - \\ \mathrm{Mz} & - & - & - & 60 & 13 & - & 20 & - & - & - & - & - & - \\ \mathrm{Fz} & 20 & 27 & 55 & 50 & 37 & - & 25 & - & - & - & - & 7 & - \\ \mathrm{S} & 20 & 27 & 55 & 50 & 38 & - & 40 & 7 & 33 & 13 & - & 27 & 25\end{array}$

Gleichenia alpina

Coprosma nitida

Tasmannia lanceolata

Restio australis

Bellendena montana

Viola species

Hydrocotyle species

Lissanthe montana

Lycopodium fastigiatum

Oxalis magallenica

Geranium species

Epacris gunnii

Rubus gunnianus

Eucalyptus gunnii

Olearia erubescens

Lagenifera stipitata

Bossiaea cordigero

Libbertia pulchella

Blechnum penna-marina

Leptospermum rupestre

Cotula reptans \&

Oreomyrrhis ciliata

Acaena species

Plantago species

Gnaphalium species

Ranunculus species

Agrostis species

Helichrysum backhousii

Diplaspis species

Deyeuxia species

Danthonia species

Helichrysum scorpioides

Carex species

Oreobolus distichus

Cotula alpina

Leptorhynchos squamatus

Helichrysum acuminatum

Veronica species

Asperula species

Craspedia glauca

Dichelachne rara

Elymus scabrum

Scleranthus biflorus

Velleia montana

Olearia algida

Conifer speciesł

Bolster shrub species\#

$\begin{array}{lrrrrrrrrrrrrr}\mathrm{Hc} & 40 & 80 & 82 & 60 & 38 & - & 10 & - & - & 7 & - & - & - \\ \mathrm{Hc} & 80 & 67 & 55 & 60 & 25 & - & 15 & - & - & 7 & - & - & - \\ \mathrm{Hr} & 100 & 67 & 91 & 20 & 25 & - & - & - & - & 40 & - & 13 & - \\ \mathrm{Hrs} & 60 & 60 & 91 & 10 & 25 & - & - & - & 33 & 7 & - & - & - \\ \mathrm{Hr} & 100 & 73 & 55 & 20 & 13 & - & - & - & - & - & - & - & - \\ \mathrm{P} & 80 & 93 & 64 & 40 & 25 & - & 5 & - & - & 13 & - & - & - \\ \mathrm{S} & - & - & 73 & - & - & - & 15 & - & - & 40 & 44 & 27 & 13 \\ \mathrm{Hr} & 20 & - & 64 & - & - & - & 5 & - & - & 7 & - & 13 & - \\ \mathrm{P} & 100 & 73 & 36 & 10 & 38 & - & 20 & 14 & - & 33 & - & 7 & 13 \\ \mathrm{P} & 100 & 100 & 45 & 10 & - & - & 15 & 7 & - & 7 & - & 47 & 13 \\ \mathrm{~Hz} & 80 & 60 & 9 & - & 37 & - & 10 & - & - & 7 & - & - & - \\ \mathrm{Mr} & 20 & 73 & 9 & 30 & 38 & - & 5 & - & - & 7 & - & 7 & 25 \\ \mathrm{Mm} & 60 & 20 & 27 & - & 13 & - & 5 & - & - & - & - & 20 & 25 \\ \mathrm{Hc} & 100 & 33 & 37 & - & 25 & - & 10 & - & 33 & - & - & - & - \\ \mathrm{Hr} & 80 & - & 18 & - & 25 & - & - & - & - & 27 & - & - & - \\ \mathrm{Hr} & 60 & 33 & - & - & 13 & - & - & - & - & 20 & - & - & - \\ \mathrm{Hz} & 60 & 27 & - & - & 37 & - & - & - & 33 & - & - & - & - \\ \mathrm{Hc} & 60 & 27 & 9 & - & - & - & 10 & - & - & 7 & - & - & - \\ \mathrm{Hr} & 60 & 47 & 9 & - & - & - & - & - & - & - & - & - & - \\ \mathrm{P} & 80 & 7 & - & - & 25 & - & - & - & - & - & - & - & - \\ \mathrm{Pt} & 60 & 7 & - & - & - & - & - & - & - & - & - & - & - \\ \mathrm{Hm} & 80 & 13 & - & - & - & - & - & - & - & - & - & - & - \\ \mathrm{Hr} & 80 & - & - & - & - & - & - & - & - & - & - & - & - \\ \mathrm{S} & 80 & - & - & - & - & - & - & - & - & - & - & - & - \\ \mathrm{g} & - & - & 36 & - & - & 100 & 75 & 64 & - & 87 & 78 & 60 & 13 \\ \mathrm{~m} & - & - & - & - & - & - & - & - & - & - & - & 47 & -\end{array}$

Species that occur in less than $50 \%$ of the quadrats for all groups have been excluded.

$\mathrm{LF}$ (life forms): $\mathrm{F}=$ fern, $\mathrm{H}=$ forb, $\mathrm{M}=$ gramminoid, $\mathrm{P}=$ grass, $\mathrm{S}=$ shrub, $\mathrm{T}=$ tree; $\mathrm{a}=$ annual/geophyte, $\mathrm{c}=\mathrm{creeping}$,

$\mathrm{d}=$ deciduous, $\mathrm{g}=$ coniferous species, $\mathrm{m}=$ mat $/$ cushion, $\mathrm{p}=$ prostrate, $\mathrm{r}=$ rosette, $\mathrm{s}=$ stoleniferous, $\mathrm{t}=$ tussock,

$\mathrm{z}=$ rhizomatous.

$\ddagger \quad$ Percentage of quadrats in each group with any conifer species present.

Percentage of quadrats in each group with any shrubs with a bolster form present. 
TABLE 3

Life form composition and environmental attributes of TWINSPAN groups*

\begin{tabular}{lrrrrrrrrrrrrr}
\hline Group & $\mathbf{1}$ & $\mathbf{2}$ & $\mathbf{3}$ & $\mathbf{4}$ & $\mathbf{5}$ & $\mathbf{6}$ & $\mathbf{7}$ & $\mathbf{8}$ & $\mathbf{9}$ & $\mathbf{1 0}$ & $\mathbf{1 1}$ & $\mathbf{1 2}$ & $\mathbf{1 3}$ \\
\hline Number of taxa† & 28 & 17 & 18 & 17 & 22 & 7 & 9 & 16 & 16 & 10 & 11 & 14 & 18 \\
Trees & - & - & - & 12 & 5 & 43 & 33 & 19 & - & - & 9 & - & - \\
$\quad$ decid vous & - & - & - & - & - & - & - & 6 & - & - & 9 & - & - \\
Shrubs & 18 & 6 & 28 & 29 & 36 & 57 & 44 & 63 & 25 & 90 & 55 & 43 & 28 \\
$\quad$ prostrate shrubs & 4 & 6 & - & 6 & 9 & 29 & - & 13 & 19 & 20 & 36 & 14 & 6 \\
Woody plants & 18 & 6 & 28 & 41 & 41 & 100 & 77 & 82 & 25 & 90 & 64 & 43 & 28 \\
Forbs & 61 & 59 & 44 & 29 & 27 & - & - & - & 19 & - & 9 & 14 & 11 \\
$\quad$ rosette forbs & 36 & 35 & 28 & 12 & 23 & - & - & - & 13 & - & 9 & 14 & 6 \\
$\quad$ creeping/stoloniferous forbs & 29 & 41 & 22 & 24 & 18 & - & - & - & 6 & - & - & - & - \\
$\quad$ annuals & - & - & - & - & - & - & - & - & - & - & - & 14 & - \\
Graminoids & 4 & 12 & 6 & 6 & 14 & - & 22 & 19 & 44 & - & 18 & 29 & 39 \\
Tussock & - & 6 & - & - & 5 & - & - & 13 & 19 & - & - & 14 & 22 \\
Grasses & 18 & 24 & 11 & 12 & 9 & - & 11 & - & 13 & 10 & 9 & 14 & 11 \\
$\quad$ tussock grasses & 4 & 6 & 6 & 6 & 5 & - & - & - & 6 & 10 & 9 & 7 & 6 \\
Ferns & - & - & 11 & 12 & 9 & - & - & - & - & - & - & - & 11 \\
Non-woody plants & 82 & 94 & 72 & 59 & 59 & - & 33 & 18 & 75 & 10 & 36 & 57 & 72 \\
$\quad$ mat forming herbs & 10 & - & - & - & - & - & - & - & 6 & - & - & 7 & 6 \\
$\quad$ rhizornatous herbs & 7 & 12 & 17 & 24 & 28 & - & 14 & 19 & 38 & - & 9 & 21 & 45 \\
Mean altitude (m) & 826 & 999 & 1142 & 851 & 837 & 967 & 962 & 1049 & 837 & 1233 & 1196 & 1195 & 925 \\
$\quad$ (st. dev.) & 24 & 126 & 111 & 16 & 13 & 6 & 136 & 70 & 75 & 49 & 54 & 46 & 82 \\
Fire score & 0 & 6 & 21 & 2 & 2 & 59 & 28 & 30 & 0 & 24 & 34 & 19 & 6 \\
Mean slope score & 1.0 & 1.3 & 1.7 & 2.1 & 1.4 & 2.0 & 1.7 & 2.4 & 2.0 & 2.3 & 1.5 & 1.3 & 1.4 \\
Mean aspect score & 2.2 & 3.0 & 2.9 & 2.7 & 2.1 & 3.0 & 2.7 & 3.0 & 3.3 & 2.3 & 2.7 & 2.9 & 2.9 \\
Mean geology score & 3.8 & 3.5 & 3.7 & 4.2 & 2.4 & 4.0 & 3.8 & 4.8 & 4.7 & 3.5 & 4.7 & 4.4 & 3.9 \\
\hline
\end{tabular}

* Life forms of the taxa occurring in less than $50 \%$ of the quadrats for the group were excluded. The indices used for fire, slope, aspect and geology are defined in the text (under "Methods").

$\dagger$ Number of taxa occurring in 50\% or more of the quadrats for each group.

\section{TABLE 4 notes}

Fire Response Classes

1 Permanent or semi-permanent $(500+y r)$ elimination of dominant species

2 Long-term $(100+y r)$ change in dominant species

3 Short-term $(100 \mathrm{yr})$ restoral of dominance, but not fire requiring

4 Eliminated if fire frequency is ever less than $400 \mathrm{yr}$

5 Requires frequent fire ( 1 in $100 \mathrm{yr}$ )

Usage response classes

1 Highly susceptible to trampling (no more than 500 people per annum per place) and not resilient, camping likely to create long-term damage

2 Highly susceptible to trampling, but resilient, camping possible without severe and prolonged damage

3 Generally resistent to and resilient from trampling
Community rarity classes (global)

1 Extremely rare synusia $\left(10 \mathrm{~km}^{2}\right.$ in toto $)$

2 Rare synusia $\left(10-200 \mathrm{~km}^{2}\right.$ in toto $)$

3 Common synusia $\left(200 \mathrm{~km}^{2}\right.$ in toto $)$

Reservation classes (global)

Percentage of $1800 \mathrm{AD}$ area of type in secure reserves

$1 \%$

$2 \quad 1-5 \%$

$3 \quad 5-25 \%$

$4 \quad 25-100 \%$

Species rarity classes

1 Rare or threatened species common

2 Rare or threatened species uncommon or absent 
TABLE 4

Attributes of Perceptible Synusiae

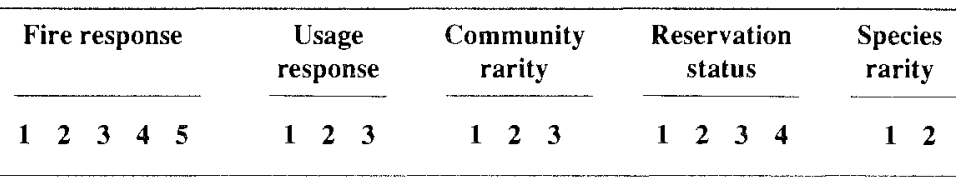

Alpine communities

Ac coniferous heath

Ag alpine grassland

Ah short alpine herbfield

As alpine heath

$\mathrm{Fj}$ fjaeldmark

$\mathrm{x}---$

$-\quad \mathrm{x}--$

$-\quad \mathrm{x}--$

$-\quad \mathrm{x}--$

Treeless subalpine communities

B heathy sedgeland

G Poa grassland

$\mathrm{H}$ herbfield

Tm Milligania tall alpine herbfield

S Sphagnum bog

Tg Gleichenia/Restio/Empodisma/ Astelia tall alpine herbfield

L Leptospermum \pm Melaleuca scrub

Eucalypt communities

Ec Eucalyptis coccifera woodland/open forest

Ed Eucalyptus delegatensis open forest

Eg Eucalyptus gunnii woodland/open forest

En Eucalyptus nitida open forest

Es Eucalyptus subcrenulata woodland/open forest

Rainforest communities

K Athrotaxis selaginoides forest

$P$ Athrotaxis cupressoides woodland/forest

Rf evergreen closed forest

D deciduous heath/scrub/forest

$\mathrm{x}----$

$-\quad-\quad x$

$-\quad x--$

$-\sim x+-$

$-\quad x--$

$-\mathrm{X}-\ldots$

$-\quad-x \mathrm{x}$

$-\quad-\mathrm{x}-$
- X -

- $\mathrm{X}-$

$-\mathrm{X}-$

$x--$

$-\quad \times-$

$-\quad \mathrm{x}-$

$-\mathrm{x}-$

$-\quad x$

- $\mathrm{X}-$

$\mathrm{X}-$

$\mathrm{X}--$

$-\mathrm{x}-$

$-\quad x-$

$-\quad-x$

$---x$

$--\quad x$

$--\quad x$

$-\quad-x$

$-\quad-x$

$-\quad-$

$-\quad \mathrm{X}-$

$-\quad \mathrm{X}-$

$-\quad-x$

$--\quad x$

$-\quad-x$

$-\quad-x$

$-\mathrm{x}$

\section{Miscellaneous}

Ro Rock or block stream
(a) quartzitic
(d) on dolerite
$-\quad \mathrm{x}$
$-x-$
$-\quad-x$
$-x$ $\mathrm{X}-$ 


\section{APPENDIX}

\section{Cradle Mountain Lake St Clair National Park 1989 Plant Census}

$\mathrm{E}=$ enderric to Tasmania, $\mathrm{I}=$ introduced to Tasmania, $\mathrm{C}=$ occurring on the CRADLE sheet, $\mathrm{R}=\mathrm{rare}$ in Tasmania. $\mathrm{P}=$ occurring on the PENCIL PINE sheet.

\section{Distribution/ status}

\section{DICOTYLEDONS}

\section{APIACEAE (UMBELLIFERAE)}

Aciphylla procumbens (F.Muell.) Benth. Actinotzs bellidioides (Hook.f.) Benth. Actinotus moorei Rodway

Actinotus suffocata (Hook.f.) Rodway

Centella cordifolia (Hook.f.) Nannf.

Dichosciadium ranunculaceum (F.Muell. ex Hook.) Domin

Diplaspis cordifolia Hook.f

Diplaspis hydrocotyle Hook.f.

Hydrocotyle hirta R.Br. ex A.Rich.

Hydrocotyle muscosa R.Br. ex A.Rich.

Hydrocotyle pterocarpa F.Muell.

Hydrocotyle sibthorpioides Lamk.

Lilaeopsis polyantha (Gand.) H.Eichler

Oreomyrrhis argentea (Hook.f.) Hook.f.

Oreomyrrhis ciliato Hook f:

Oreomyrrhis eriopoda (DC.) Hook.f.

Oreomyrrhis sessiliflora Hook.f.

\section{ASTERACEAE (COMPOSITAE)}

Abrotanella forsteroides (Hook.f.) Benth. Abrotanella scapigera (F.Muell.) Benth.

Bellis perennis $\mathbf{L}$.

Brachyscome angustifolia A.Cunn.ex DC. var. angustifolia

Brachyscome decipiens Hook.f.

Brachyscome spathulata Gaud.

ssp. glabra (DC.) Stace

Brachyscome tenuiscapa Hook,f.

Celmisia asteliifolia Hook.f.

Celmisia saxifraga (Benth.) W.M.Curtis

Cirsium vulgare (Savi) Ten.

Cotula alpina (Hook.f.) Hook.f.

Cotula filicula (Hook.f.) Benth.

Cotula reptans (Benth.) Benth.

Craspedia alpina Backh. ex Hook.f.

Craspedia glauca (Labill.) Sprengel

var. gracilis Hook.f.

Erigeron pappocromus Labill.

Erigeron stellatus (Hook.f.) W.M.Curtis

Ewartia catipes (DC.) P.Beauv.

Ewartia meredithiae (F.Muell.) P.Beauv.

E C

C

E C P

C

E C P

E C

C $\mathrm{P}$

$\mathrm{P}$

C P

C $\mathrm{R}$

C $\mathrm{P}$

E C

E C

E C P

I C P

E C P

C P

E C

I C P

C P

C P

C. $\mathrm{P}$

$P$

E C P

E C

E C
Ewartia planchonii (Hook.f.) P.Beauv

Gnaphalium collinum Labill.

Gnaphalium fordianum M.Gray

Gnaphalium supinum $\mathrm{l}_{\text {. }}$.

Gnaphalium traversil Hook,f.

Gnaphalium umbricola J.H.Willis

Helichrysum acuminatum DC.

C

C P

Helichrysum backhousii (Hook.f.) F.Muell. ex Benth. var. backhousii var. oreophilum W.M.Curtis

E C P

$\mathrm{E}$

Helichrysum expansifolium (P.Morris \& J.H.Willis) N.Burb.

Helichrysum hookeri (Sonder) Druce

Helichrysum ledifolium (DC.) Benth.

Helichrysum milliganii Hook.f.

Helichrysum pumilum Hook,f. var. pumilum var. spathulatum A.M.Buchanan

Helichrysum rosmarinifolium (Labill.) Benth. Helichrysum rutidolepis DC.

Helichrysum scorpioides Labill.

Helipterum albicans (A.Cunin.) DC.

var. incanum (Hook.) Paul G.Wilson

Hypochoeris glabra $\mathbf{L}$.

Hypochoeris radicata $\mathrm{L}$.

Lagenifera stipitata (Labill.) Druce

Leptorhynchos squamatus (Labill.) Less.

Leontodon taraxacoides (Vill.) Merat

Microseris lanceolata (Walp.) Schultz-Bip.

Olearia algida Wakef.

Olearia erubescens (DC.) Dippel

Olearia ledifolia (DC.) Benth.

Olearia myrsinoides (Labill.) F.Muell. ex Benth.

Olearia obcordata (Hook.f.) Benth.

Olearia persoonioides (DC.) Benth.

Olearia phlogopappa (Labill.) DC.

Olearia pinifolia (Hook.f.) Benth.

Olearia stellulata (Labill.) DC.

Olearia tasmanica (Hook.f.) W.M.Curtis E C

Podolepis jaceoides (Sims) Voss

E C

C

E C

E C $P$

E C P

E C

C $\mathrm{P}$

C $\mathrm{P}$

E P R

I $P$

I C

C P

$\mathrm{P}$

I C

C P

$P$

C P

E C P

Pterygopappus lawrencii Hook.f.

Senecio gunnii (Hook.f.) Belcher

Senecio jacobea $\mathrm{L}$.

$\mathrm{E} C \mathrm{P}$

$\mathrm{E} C \mathrm{P}$

$\mathrm{C} P$

E C P

$\mathrm{CP}$

E C

Senecio lautus Forst.f. ex Willd.

Senecio leptocarpus DC.

I P

Senecio minimus Poiret

Senecio pectinatus DC. 
var, ochro leuca F.Muell.

var. pectinatus

Sonchus oleraceus L.

Taraxacum officinale Weber

BRASSICACEAE (CRUCIFERAE)

Cardamine gunnii Hewson

Cardamine paucijuga Turcz.

Cheesemania radicata (Hook.f.) O.E.Shultz

\section{CALLITRICHACEAE}

Callitiche brachycarpa Hegelm.

\section{CAMPANULACEAE}

Pratia surrepens (Hook.f.) F.E.Wimmer

Wahlenbergia ceracea Loth.

Wahlenbergia saxicola A.DC.

\section{CARYOPHYLLACEAE}

Cerastium fontanum Baumg.

Cerastium glomeratum Thuill.

Colobanthus apetalus (Labill.) Druce

Sagina procumbens L.

Scleranthus biflorus (Forst. \& Forst.f.) Hook.f. C P

Scleranthus brockiei P.A.Williamson

\section{CASUARINACEAE}

Allocasuarina monilifera (L.Johnson)

L.Johnson

C

Allocasuarina zephrea L.Johnson

CLUSIACEAE (GUTTIFERAE)

Hypericum gramineum Forst.f.

Hypericum japonicum Thunb.

$\mathrm{P}$

C P

\section{CUNONIACEAE}

Anodopetalum biglandulosum A.Cunn.

ex Hook.f.

Bauera rubioides Andrews

E C

C

DILLENIACEAE

Hibbertia procumbens (Labill.) DC.

Hibbertia serpyllifolia R.Br. ex DC.

\section{DONATIACEAE}

Donatia novae-zelandiae Hook.f.

\section{DROSERACEAE}

Drosera arcturi Hook.

Drosera binata Labill.

Drosera peltata Thunb.

Drosera pygmaea DC.

$$
\begin{array}{lll}
\text { E } & \text { C } & \text { P } \\
& \text { C } & \text { P } \\
\text { I } & \text { P } \\
\text { I } & & \text { P }
\end{array}
$$

C

C

E C P

I P

I P

C $\mathrm{P}$

I C P

E C

E C R

,






\section{EUCRYPHIACEAE}

Eucryphia lucida (Labill.) Baill.

E C

\section{FABACEAE (LEGUMINOSAE)}

Acacia dealbata Link

Acacia mucronata Willd. ex Wendl.f.

Bossiaea cordigera Benth. ex Hook.f.

Bossiaea riparia A.Cunn. ex Benth.

Oxylobi um ellipticum (Labill.) R.Br.

Pultenaea dentata Labill.

Pultenaea juniperina Labill.

Pultenaea subumbellata Hook.

Trifolium repens $\mathrm{L}$.

\section{FAGACEAE}

Nothofagus cunninghamii (Hook.) Oersted

Nothofagus gunnii (Hook.f.) Oersted

\section{GENTIANACEAE}

Gentianella diemensis (Griseb.) J.H.Willis

\section{GERANIACEAE}

Geranium potentilloides L'Herit. ex DC.

Geranium sessiliflorum Cav.

ssp. brevicaule (Hook.) Carolin

\section{GOODENIACEAE}

Scaevola hookeri (Vriese) F.Muell. ex Hook.f. C

Velleia montana Hook.f.

\section{GUNNERACEAE}

Gunnera cordifolia Hook.f.

\section{HALORAGACEAE}

Gonocarpus micranthus Thunb.

ssp. micranthus

Gonocarpus montanus (Hook.f.) Orch.

Gonocarpus serpyllifolius Hook.f.

Gonocarpus teucrioides DC.

Myriophyllum aquaticum (Vell.) Verdc.

Myriophyllum pedunculatum Hook.f.

\section{LAMIACEAE (LABIATAE)}

\section{Ajuga australis}

Prunella vulgaris $\mathrm{L}$.

\section{LENTIBULARIACEAE}

Utricularia dichotoma Labill.

Utricularia monanthos Hook.f.

\section{LOGANIACEAE}

Mitrasacme archeri Hook.f.

Mitrasacme montana Hook.f. ex Benth.

$\mathrm{C}$

C P

C P

C P

C P

C P

I C P

C P

E C P

C P

C P

P

$P$

$P$

Mitrasacme pilosa Labill.

Mitrasacme serpyllifolia R.Br.

\section{MENYANTHACEAE}

Liparophyllum gunnii Hook.f.

(1)




\section{PITTOSPORACEAE}

Billardiera longiflora Labill.

Pittosporum bicolor Hook.

\section{PLANTAGINACEAE}

Plantago coronopus $\mathrm{L}$.

I $\mathrm{C}$

Plantago daltonii Decne.

Plantago glabrata Hook.f.

Plantago glacialis B.Briggs, Carolin \& Pulley

Plantago gunnii Hook.f.

Plantago lanceolata L.

Plantago major $\mathbf{L}$.

Plantago paradoxa Hook.f.

Plantago tasmanica Hook.f.

var. archeri (Hook.f.) W.M.Curtis

var. tasmanica

\section{POLYGONACEAE}

Comespermum retusum Labill.

Muehlenbeckia axillaris (Hook.f.) Walp.

Rumex acetosella $\mathrm{L}$.

Rumex obtusifolius $\mathrm{L}$.

\section{PORTULACACEAE}

Montia australasica (Hook.f.) Pax \& Hoffm.

\section{PRIMULACEAE}

Anagallis arvensis $\mathrm{L}$.

\section{PROTEACEAE}

Agastachys odorata R.Br.

Banksia marginata Cav.

Bellendena montana R.Br.

Cenarrhenes nitida Labill.

Grevillea australis $\mathrm{R} . \mathrm{Br}$.

Hakea epiglottis Labill.

Hakea lissosperma R.Br.

Hakea microcarpa $\mathrm{R}$. Br.

Lomatia polymorpha R.Br.

Lomatia tinctoria R.Br.

Orites acicularis $\mathrm{R} . \mathrm{Br}$.

Orites diversifolia $\mathrm{R}$. Br.

Orites revoluta R.Br.

Persoonia gunnii Hook.f.

Persoonia juniperina Labill.

Persoonia muelleri (P.Parm.) Orch.

Telopea truncata (Labill.) R.Br.

\section{RANUNCULACEAE}

Anemone crassifolia Hook.

Caltha phylloptera A.W.Hill

Clematis aristata R.Br. ex DC.

Clematis vitalba $\mathbf{L}$.

E

C P

E C P

E C

$P$

E

$\mathrm{C}$

E

E P

$\mathrm{E}$

E C P

$\mathrm{E}$

E C P

E C

E $P$

E C P

E C P

E C R

C
Ranunculus collinus R.Br. ex DC.

Ranunculus decurvus (Hook.f.) Melville

E C

Ranunculus glabrifolius Hook.

Ranunculus nanus Hook.

Ranunculus pascuinus (Hook.f.) Melville

Ranunculus triplodontus Melville

E

E C P

\section{RHAMNACEAE}

Cryptandra alpina Hook.f.

Pomaderris apetala Labill.

E

\section{ROSACEAE}

Acaena montana Hook.f.

Acaena novae-zelandiae Kirk

E C P

C P

Aphanes arvensis $\mathrm{L}$.

I $\mathrm{C}$

Rubus gunnianus Hook.

E C P

\section{RUBIACEAE}

Asperula gunnii Hook.f.

C P

Coprosma hitella Labill.

Coprosma moorei F.Muell. ex Rodway

C P R

Coprosma nitida Hook.f.

C P

Coprosma perpusilla Colenso

Coprosma pumila Hook.f.

C P

Coprosma quadrifida (Labill.) Robinson

Galium australe DC.

$\mathrm{C}$

Nertera depressa Banks \& Soland. ex Gaertner C

\section{RUTACEAE}

Boronia citriodora Gunn ex Hook.f.

C P

Boronia parviflora Smith

$\mathrm{C}$

Boronia pilosa Labill.

Boronia rhomboidea Hook.

Phebalium montanum Hook.

C P

Phebalium oldfieldii (F.Muell.) F.Muell.

ex Benth.

E

Phebalium squameum (Labill.) Engl.

E C

E C P

\section{SANTALACEAE}

Exocarpos humifusus R.Br.

Exocarpos nana Hook.f.

E C P

Leptomeria glomerata F.Muell.

E C

\section{SCROPHULARIACEAE}

Euphrasia collina R.Br. ssp. diemenica (Sprengel) W.R.Barker

E C P

Euphrasia gibbsiae Du Rietz ssp. discolor W.R.Barker ssp. gibbsiae

E C

$\mathrm{E}$

E

ssp. microdonta W.R.Barker

E

Euphrasia hookeri Wettst.

Euphrasia striata R.Br.

E C

$$
\text { ex Hook.f. }
$$


Ourisia integrifolia R.Br.

Veronicacalycina $\mathrm{R} . \mathrm{Br}$.

Veronicagracilis $\mathrm{R} . \mathrm{Br}$.

Veronica nivea Lindley

Veronica serpyllifolia $\mathrm{L}$.

\section{STYLIDIACEAE}

Forsterabellidifolia Hook.f.

Phyllachne colensoi (Hook.f.) Bergg.

Stylidium graminifolium Swartz

\section{THYMELAEACEAE}

Drapetestasmanicus Hook.f.

Pimelea drupacea Labill.

Pimelea lindleyana Meissner

Pimelea sericea R.Br.

\section{TREMANDRACEAE}

Tetratheca procumbens Gunn ex Hook.f.

\section{URTICACEAE}

Australina pusilla (desf. ex Puiret) Cavdich

Urtica incisa Poiret

\section{VIOLACEAE}

Viola betonicifolia Smith

Viola hederacea Labill.

\section{WINTERACEAE}

Tasmannia lanceolata (Poiret) A.C.Smith

\section{MONOCOTYLEDONS}

\section{CENTROLEPIDACEAE}

Centrolepis monogyna (Hook.f.) Benth. Centrolepis muscoides (Hook.f.) Hieron. Gaimardia fitzgeraldii F.Muell. \& Rodway Gaimardia setacea Hook.f.

\section{CYPERACEAE}

Carex sp. aff. appressa

Carex appressa R.Br.

Carex cephalotes F.Muell.

Carex gaudichaudiana Kunth

Carex hypandra F.Muell. ex Benth.

Carpha alpina $\mathrm{R} . \mathrm{Br}$.

Carpha curvata W.M.Curtis

Carpha rodwayi W.M.Curtis

Eleocharis gracilis R.Br.

Gahnia grandis (Labill.) S.T.Blake

Gymnoschoenus sphaerocephalus (R.Br.)

Hook.f.

Isolepis aucklandica Hook.f.

Isolepis crassiuscula Hook.f.

E C P
C P
I C P
C
P

$\mathrm{E}$

C R

C P

C P

C P

E $P$

E C P

E P

C P

C P

C P
E C P

$\mathrm{E} \mathrm{C}$

E C
E C P

C P

$R$

C P

$\mathrm{C}$

C P

E

E
HYDATELLACEAE

Hydatella filamentosa (Rodway) W.M.Curtis E C

\section{HYPOXIDACEAE}

Campynema lineare Labill.

E C P

\section{IRIDACEAE}

Diplarrena latifolia Benth.

E C P

Diplarrena moraea Labill.

Isophysis tasmanica (Hook.) T.Moore $\because$ E C P

Libertia pulchella Sprengel

C P

Patersonia fragilis (Labill.) Ashers. \& Graebner

\section{JUNCACEAE}

Juncus antarcticus Hook.f.

Juncus falcatus E.Meyer
C

C P

$P$
E

E C P

C P

$\mathrm{C}$

C P

$P$

C P

C P

C P

Juncus pauciflorus $\mathrm{R} . \mathrm{Br}$.

Juncus planifolius R.Br.

Juncus sandwithii Lourteig

C

Luzula atrata Edgar

Luzula australasica Steudel

E

$$
\text { Luzula flaccida (Buchenau) Edgar }
$$

Luzula modesta Buchenau

Luzula novae-cambriae Gandoger

LILIACEAE

Astelia alpina $\mathrm{R} . \mathrm{Br}$. var. alpina

Blandfordia punicea (Labill.) Sweet

E C

Dianella revoluta $\mathrm{R} . \mathrm{Br}$.

C P

Dianella tasmanica Hook.f.

C P

Drymophila cyanocarpa R.Br.

C P

C P 
Milligania densiflora Hook.f.

E C P

Milligania lindoniana Rodway ex W.M.Curtis E C

Milligania stylosa (F.Muell, ex Hook.f.)

F.Muell. ex Benth.

E

Wurmbea unifiora (R.Br.) T.Macfarlane

E

\section{ORCHIDACE AE}

Acianthus viridis Hook.f.

Caladenia lyallii Hook.f.

Corybas diemenicus (Lindley) Reichb.f.

Eriochilus cucullatus (Labill.) Reichb.f."

Prasophyllum alpinum $\mathrm{R} . \mathrm{Br}$.

Pterostylis falcata R.Rogers

\section{POACEAE (GRAMINEAE)}

Agrostis avenacea J.Gmelin

Agrostis billardieri R.Br.

Agrostis gigantea Roth

Agrostis aff hiemalis (Walt.) Britton et al.

Agrostis parviflora $\mathrm{R} . \mathrm{Br}$.

Agrostis rudis Roemer \& Schultes

Agrostis venusta Trin.

Amphibromus archeri (Hook.f.) P.Morris

Amphibromus recurvatus Swallen

Australopyrum pectinatum (Labill.) A.Löve

Dactylis glomerata $\mathbf{L}$.

Danthonia fortunae-hibernae Renvoize

Danthonia gracilis Hook.f.

Danthonia nudiflora P.Morris

Danthonia pauciflora R.Br.

Deyeuxia accedens Vick.

Deyeuxia brachyathera (Stapf) Vick.

Deyeuxia carinata Vick.

C P

I $\mathrm{P}$

E C P

C $\mathrm{P}$

C P

E C

$\mathrm{E}$

$\mathrm{R}$

C

Deyeuxia monticola (Roemer \& Schultes) Vick.

Deyeuxia quadriseta (Labill.) Benth.

Dichelachne rara (R.Br.) Vick.

Ehrharta distichophylla Labill.

Ehrharta stipoides Labill.

Ehrharta tasmanica (Hook.f.) Willemse

var. subalpina (F.Muell. ex Benth.)

Willemse

E C P

var, tasmanica

C P

Elymus scabrus (Labill.) A.Löve

Erythranthera australis (petrie) Zotov

Hierochloe fraseri Hook.f. ex Rodway

C

C P

Hierochloe redolens (Vahl) Roemer \& Schultes C

Holcus lanatus L.

I C P

Pentapogon quadrifidus (Labill.) Baillon $\quad$ C P

Poa annua L.

I C P

Poa gunnii Vick.

E C P

Poa labillardieri Steudel

var. acris Vick.

var. labillardieri

E C P

C P
Poa saxicola R.Br.

C P

Poa sieberiana Sprengel

Stipa rudis Sprengel

ssp. australis J.Everett \& S.Jacobs

Trisetum spicatum (L.) Richter

ssp. australiense Hulten

PATAMOGETONACEAE

Potamogeton tricarinatus F.Muell. \& A.Benn. ex A.Benn.

\section{RESTIONACEAE}

Calorophus elongatus Labill.

E

Empodisma minus (Hook.f.) L.Johnson \& Cutler

C P

Leptocarpus tenax (Labill.) R.Br.

Lepyrodia tasmanica Hook.f.

Restio australis R.Br.

C P

Restio complanatus R.Br.

C P

C P

Restio monocephalus R.Br.

E

Restio tetraphyllus Labill.

XYRIDACEAE

Xyris marginata Rendle

E

Xyris muelleri Malme

E

Xyris operculata Labill.

GYMNOSPERMS

\section{CUPRESSACEAE}

Diselma archeri Hook.f.

E C P

PHYLLOCLADACEAE

Phyllocladus aspleniifolius (Labill.) Hook.f. E C P

\section{PODOCARPACEAE}

Microcachrys tetragona (Hook.) Hook.f.

E C P

Microstrobos niphophilus Garden \&

L.Johnson

Podocarpus lawrencei Hook.f.

E C

C P

\section{TAXODIACEAE}

Athrotaxis cupressoides D.Don.

E C P

Athrotaxis laxifolia Hook.

E C P

Athrotaxis selaginoides D.Don.

E C

PTERIDOPHYTES

\section{ASPIDIACEAE}

Polystichum proliferum (R.Br.) C.Pres!

C P

Poa pratensis $\mathrm{L}$.

ASPLENIACEAE

Asplenium terrestre Brownsey 


\section{BLECHNACEAE}

Blechnum chambersii Tind.

Blechnum fluviatile (R.Br.) E.J.Löwe ex Salom Blechnum nudum (Labill.) Mett. ex Luerss.

Blechnum penna-marina (Poiret.) Kuhn

C P

Blechnum vulcanicum (Blume) Kuhn

Blechnum wattsii Tind.

C P

\section{DAVILLIACEAE}

Rumohra adiantiformis (Forst.f.) Ching

\section{DENNSTAEDTIACEAE}

Histiopteris incisa (Thunb.) J.Smith.

Hypolep is rugosula (Labill.) J.Smith

Pteridium esculentum (Forst.f.) Cockayne

\section{DICKSONIACEAE}

Dicksonia antarctica Labill.

\section{GLEICHENIACEAE}

Gleichenia alpina R.Br.

Gleichenia dicarpa R.Br.

Sticherus lobatus Wakef.

\section{GRAMMITIDACEAE}

Ctenopteris heterophylla (Labill.) Tind.

Grammitis biliardieri Willd.

Grammitis magellanica Desv.

ssp. nothofagetii Parris

Grammitis meridionalis Parris

Grammitis poeppigiana (Mett.) Pichi-Serm.

\section{HYMENOPHYLLACEAE}

Apteropteris applanata A.M.Gray \&

$$
\text { R.G.Williams }
$$

Hymenophyllum australe Willd.

Hymenophyllum cupressiforme Labill.

Hymenophyllum flabellatum Labill.

Hymenophyllum peltatum (Poiret.) Desv.

Hymenophyllum rarum $\mathrm{R}$.Br.

\section{ISOETACEAE}

Isoetes gunnii A.Braun

\section{LINDSAEACEAE}

Lindsaea linearis Swartz

\section{LYCOPODIACEAE}

Lycopodium australianum Herter

Lycopodium fastigiatum $\mathrm{R} . \mathrm{Br}$.

Lycopodium laterale $\mathrm{R} . \mathrm{Br}$.

Lycopodium scariosum Forst.f.

POLYPODIACEAE

Microsorium diversifolium (Willd.) Copel.

$\mathrm{P}$

\section{Species Found Outside the National Park Within the Pencil Pine Planning Area \\ DICOTYLEDONS}

APIACEAE (UMBELLIFERAE)

Trachymene humilis (Hook.f.) Benth.

C P

$\mathrm{P}$

$\mathrm{P}$

C P

$\mathrm{C} \mathrm{P}$

C

$\mathrm{P}$

$\mathbf{R}$

\section{CYPERACEAE}

Carex breviculmis R.Br.

Carex inversa $\mathrm{R} . \mathrm{B} \mathrm{r}$

E C P

$P$ JUNCACEAE

$\mathrm{P} \quad J u n c u s$ aff. astreptus

C P

C $\mathbf{P}$

E C

C

C

C P

$\mathrm{C}$

\section{ORCHIDACEAE}

Diuris pedunculata $\mathrm{R} . \mathrm{Br}$.

POACEAE (GRAMINEAE)

Danthonia penicillata (Labill.) R.Br.

Poa tenera F.Muell. ex Hook.f.

\section{PTERIDOPHYTES}

\section{OPHIOGLOSSACEAE}

Botrychium lunaria (L.) Swart
R

$\mathbf{R}$ 